\title{
ASSESSING ORAL HEALTH-RELATED QUALITY OF LIFE IN CHILDREN AND ADOLESCENTS: A SYSTEMATIC REVIEW AND STANDARDIZED COMPARISON OF AVAILABLE INSTRUMENTS
}

Authors: Carlos Zaror ${ }^{1,2,3}$, Yolanda Pardo ${ }^{4,5}$, Gerardo Espinoza-Espinoza ${ }^{2,6}$, Àngels Pont ${ }^{4,5}$, Patricia Muñoz-Millán ${ }^{1,2}$, María José Martínez-Zapata ${ }^{5,7}$, Gemma Vilagut ${ }^{4,5}$, Carlos G Forero $^{5,4,8}$, Olatz Garin ${ }^{4,5}$, Jordi Alonso ${ }^{4,5,8}$, Montse Ferrer ${ }^{4,5,3}$

1 Department of Pediatric Dentistry and Orthodontics, Faculty of Dentistry, Universidad de La Frontera, Temuco, Chile.

2 Center for Research in Epidemiology, Economics and Oral Public Health (CIEESPO), Faculty of Dentistry, Universidad de La Frontera, Temuco, Chile.

3 Universitat Autònoma de Barcelona, Barcelona, Spain

4 Health Services Research Group, IMIM (Hospital del Mar Medical Research Institute), Barcelona, Spain

5 CIBER Epidemiología y Salud Pública (CIBERESP), Barcelona, Spain

6 Department of Public Health, Faculty of Medicine, Universidad de La Frontera.

7 Iberoamerican Cochrane Centre, Biomedical Research Institute Sant Pau (IIB Sant Pau)

8. Universitat Pompeu Fabra (UPF), Barcelona, Spain

\section{Corresponding authors:}

Montse Ferrer, PhD, MD.

Health Services Research Group, IMIM (Hospital del Mar Medical Research Institute),

Doctor Aiguader, 88, 08003 Barcelona, Spain.

E-mail address: mferrer@imim.es

Carlos Zaror, MSc, DDS

Manuel Montt \#112, Department of Pediatric Dentistry and Orthodontic, Faculty of

Dentistry, Universidad de La Frontera, Temuco, Chile

Phone/Fax: +56-45-2325776

E-mail: carlos.zaror@ufrontera.cl

Keywords: Oral health, quality of life, questionnaires, psychometrics, outcome assessment, child. 


\section{ABSTRACT}

Objectives: To obtain a systematic and standardized evaluation of the current evidence on development process, metric properties and administration issues of oral health-related quality of life instruments available for children and adolescents.

Materials and Methods: A systematic search until October 2016 was conducted in PubMed, Embase, Lilacs, SciELO and Cochrane databases. Articles with information regarding the development process, metric properties, and administration issues of pediatric instruments measuring oral health-related quality of life were eligible for inclusion. Two researchers independently evaluated each instrument applying the EMPRO (Evaluating Measures of Patient-Reported Outcomes) tool. An overall and seven attribute-specific EMPRO scores were calculated (range 0-100, worst to best): measurement model, reliability, validity, responsiveness, interpretability, burden and alternative forms.

Results: We identified 18 instruments evaluated in 132 articles. From five instruments designed for preschoolers, Early Childhood Oral Health Impact Scale (ECOHIS) obtained the highest overall EMPRO score (82.2). Of 9 identified for schoolchildren and adolescents, the best rated instrument was Child Perceptions Questionnaire 11-14 (82.1). Among the four instruments developed for any age, Family Impact Scale (FIS) obtained the highest scores (80.3).

Conclusion: The evidence supports the use of ECOHIS for preschoolers, while the age is a key factor when choosing among the four recommended instruments for schoolchildren and adolescents. Instruments for specific conditions, symptoms or treatments need further research on metric properties.

Clinical Relevance: Our results facilitate decision-making on the correct oral healthrelated quality of life instrument selection for any certain study purpose and population during the childhood and adolescence life cycle. 


\section{INTRODUCTION}

Oral diseases are highly prevalent worldwide despite the improvement in oral health indices initiated in the last decades of the XX century [1-4]. It is well known that their consequences on children are serious and can affect their quality of life [5-10]. Patientreported outcomes, together with clinical indicators, can jointly provide a more comprehensive assessment of the patient's oral health [11]. The oral health-related quality of life has been defined as a multidimensional concept which includes a subjective evaluation of the individual's oral health, functional well-being, expectations and satisfaction with care, and sense of self [11].

As the increase in the development of patient-reported outcomes is a general phenomenon, several attempts have been made to systemize evaluation criteria. One of the first approximations was performed by the Medical Outcome Trust, which published an exhaustive series of recommendations regarding the ideal attributes of patient-reported outcomes [12]. Nowadays, the most established tools are the Evaluating Measures of Patient-Reported Outcomes (EMPRO) [13], based on the Medical Outcome Trust proposal [12], and the Consensus-based Standards for the selection of health status Measurement Instruments (COSMIN) [14]. While the latter was originally developed as a checklist for evaluating the methodological quality of each study focused on measurement properties, the EMPRO was designed to carry out an overall assessment of each instrument by taking into account both the methodology applied and the results obtained, based on all the available evidence. The EMPRO is a valid and reliable tool that has proven its usefulness in comparing the performance of generic [13], and disease-specific patient-reported outcomes [15-19].

In the last decade, a large number of oral health-related quality of life questionnaires have been developed for children and adolescents. Unfortunately, information about their development process, metric properties and administration issues is disperse. To the best of our knowledge, only one systematic review has been published and it was centered on the three instruments currently most used for children, [20] the Child Perceptions

Questionnaire, the Child Oral Impacts on Daily Performances and the Child Oral Health Impact Profile. Therefore, an extended systematic review of all the available instruments to 
assess oral health-related quality of life during childhood and adolescence is necessary in order to know the characteristics, pros and cons of each one, and to facilitate selection according to clinical or research requirements.

Accordingly, the research question to answer is: To what extent is each instrument metrically robust and suitable to assess children's and adolescents' oral health-related quality of life? The aim of our study was to obtain a systematic and standardized evaluation of the current evidence on the development process, metric properties and administration issues of the oral health-related quality of life instruments available for population aged 018 years, by applying the EMPRO tool. 


\section{METHODS}

Protocol

We used Preferred Reporting Items for Systematic Reviews and Meta-analysis (PRISMA) guidelines for the reporting of this systematic review [21].

\section{Eligibility Criteria}

Articles presenting information on the development process, the psychometric properties and the administration of oral health-related quality of life instruments in children and adolescents were eligible for inclusion. Articles written in English, Spanish, Portuguese, French, German and Italian were eligible, including both studies of original instruments as well as those of other country versions. Studies were excluded if they had used generic instruments to measure oral health, or applied oral health-related quality of life tools developed for the adult population in studies with children. Articles describing protocols, conference summaries, and case studies, as well as letters to the editor, were also excluded.

\section{Information Sources and Search}

A systematic search until October 2016 was conducted, initial dates depending on database: from 1966 in Medline, 1974 in Embase, 1982 in Lilacs, 1998 in SciELO and 2008 in Cochrane Library. It was complemented by a manual review of the references of the included articles and in two online databases of patient-reported outcome instruments: Patient-Reported Outcomes and Quality of Life Instruments Database (https://eprovide.mapi-trust.org), and BiblioPRO (www.bibliopro.org). The details of the search strategy used in Medline are listed in supplementary data (Online Resource 1).

\section{Study Selection}

Titles, abstracts, and full-text articles were selected independently by two investigators (CZ and either PM or GE) to verify their eligibility. In cases of discrepancy, the decision was made by a third reviewer (YP). 


\section{Data collection process}

Each oral health-related quality of life instrument was evaluated independently by two reviewers, which is the minimum recommended when assessing information that involves subjective interpretation [22]. Concordance between pairs of reviewers was examined by calculating the one-way random effects intraclass correlation coefficient (ICC) for absolute agreement. In case of evaluation discrepancies, they were first resolved through consensus and then, if necessary, by a third reviewer. Experts were identified and invited because of their knowledge and experience in patient-reported outcomes measurement: fourteen belonged to the team that developed the EMPRO, and eighteen were researchers who participated in a training course focused on how to support selection of the most adequate patient-reported outcome through a standardized assessment of metric properties and issues related to its administration with the EMPRO system.

\section{Evaluating Measures of Patient-Reported Outcomes (EMPRO)}

The EMPRO tool is composed of 39 items divided into 8 attributes: "conceptual and measurement model" (concepts and population intended to assess); "reliability" (to what degree an instrument is free from random error); "validity" (to what degree an instrument measures what it intends); "responsiveness" (ability to detect change over time); "interpretability" (assignment of meanings to instrument scores); "burden” (time, effort and other demands for administration and response); "alternative modes of administration” (i.e., self- or interviewer-administered, telephone or computer-assisted interview); and "crosscultural and linguistic adaptations” (equivalence across translated versions) [13]. The last attribute was not completed because it was beyond the scope of this study.

All EMPRO attributes and items are accompanied by a short description, to facilitate understanding and to guarantee a standardized application during the evaluation process. Agreement with each item can be answered on a four-point Likert scale, from 4 (strongly agree) to 1 (strongly disagree), and there is also a "no information" option. Five items allow a "not applicable" reply. Items for which the response option was "no information" were assigned a score of 1 (lowest possible score).

Statistical analysis

Attribute-specific scores and an overall score were calculated for each instrument. The mean of the applicable items was calculated for each attribute when at least $50 \%$ of 
them were rated. Mean responses were linearly transformed into a range from 0 (worst possible score) to 100 (best possible score). Separate subscores for the "reliability" and "burden" attributes were calculated, as they are composed of two components each: "internal consistency" and "reproducibility" for reliability, as well as "respondent" and "administrative" for burden. For reliability, as the two components represent different approaches to examine one same attribute, the highest subscore was chosen. For burden, however, as the two components assess different aspects of the same attribute, the final score was calculated as their mean.

In addition, an overall score was computed by calculating the mean of the five metric-related attributes: "conceptual and measurement model," "reliability," "validity," "responsiveness to change" and "interpretability." The overall score was only calculated when at least three of these five attributes had a score.

EMPRO scores were considered reasonably acceptable if they reached at least 50 points (half of the 100 maximum theoretical points). This threshold was chosen based on the global recommendations made by the reviewers in the first two EMPRO studies $[15,13]$.

Oral health-related quality of life instruments were examined separately according to the target population: preschoolers ( $<6$ years old), schoolchildren and adolescents (6-18 years old) and the whole childhood and adolescence life cycle (0-18 years old). 


\section{RESULTS}

Results of the search

The search identified 3,832 references (Fig. 1). After excluding 577 duplicates and reviewing titles and abstracts, 146 articles were read in full text. Subsequently, 25 were excluded, 21 because they included only adult samples and 4 due to their lack of metric property information. Eleven articles were identified by hand search and online patientreported outcomes databases. Thus, a total of 132 full text articles were considered at the EMPRO evaluation of 18 instruments (see list of references in Online Resource 2). The number of articles found per instrument ranged from 1 to 54, with some articles providing information on more than one instrument. The intraclass correlation coefficient for the overall EMPRO score between pairs of reviewers was 0.84 indicating a high agreement before consensus process.

--- Fig. 1, about here ---

\section{Characteristics of instruments}

Table 1 shows in alphabetic order the 5 instruments applicable to preschoolers, which were published between 2002 and 2014. All were designed for oral diseases in general, proxy-administration, and developed in English-speaking countries, except for the Dental Discomfort Questionnaire (DDQ) symptom-specific scale, focused on discomfort and/or pain, and the Oral Health-related Early Childhood Quality Of Life (OH-ECOQOL) developed in India. Only two, the Michigan Oral Health-Related Quality of Life scale (Michigan-OHRQoL) and the Scale of Oral Health Outcomes for 5-year-old children (SOHO-5), also have a version for child self-administration.

---Table 1, about here ---

For schoolchildren and adolescents, 9 instruments were identified (Table 2): 4 were generic, 2 condition-specific (for hypodontia and malocclusion), 1 symptom-specific for pain, 1 treatment-specific for fixed appliances, and 1 econometric. They were developed between 1998 and 2016, in English, and to be self-administered, with the exception of the Child-Oral Impact on Daily Performance Index (Child-OIDP), developed in Thai to be interviewer-administered.

---Table 2 about here --- 
Four instruments designed for children and adolescents of any age (0-18 years) were published after 2002 (Table 3). They were all designed in English, adapted to different cultures and administered through a parent or caregiver, although Pediatric Quality of Life Inventory ${ }^{\mathrm{TM}}$ Oral Health Scale ${ }^{\mathrm{TM}}$ (PedsQL-OH ${ }^{\mathrm{TM}}$ ) and Pediatric Oral health-related Quality of Life (POQL) had also a self-administered version for specific children's ages.

It is important to clarify that four of the above-mentioned instruments form part of the Child Oral Health Quality of Life, which considers not only the children's perception measured with Child Perceptions Questionnaires (CPQ8-10 or CPQ11-14), but also that of the parents with the Parental-Caregiver Perceptions Questionnaire (P-CPQ), and the impact of the child's oral problems on the family with the Family Impact Scale (FIS). Each one of these four instruments has been evaluated separately within their target population group.

--- Table 3, about here---

\section{Results of the EMPRO ratings}

The instrument with the highest overall score in preschoolers (Fig. 2) was the Early Childhood Oral Health Impact Scale (ECOHIS) with 82.2 points, in schoolchildren it (Fig. 3) was the CPQ11-14 with 82.1, and for children and adolescents of any age (Fig. 4) the FIS with 80.3 points. Detailed EMPRO results for any specific criteria and attributes are presented in supplementary material (Online Resource 3).

--- Fig. 2, 3, and 4 about here---

All the questionnaires were scored over 50 in the conceptual model attribute, except for the Michigan-OHRQoL (Fig. 2), Oral Health-Related Quality of Life for patients with Hypodontia (OHRQoL-Hypodontia), Impact of Fixed Appliances Questionnaire (IFAQ) and Dental Freetime Trade-Off Scale (DFTO) (Fig. 3). Reliability scores ranged from 16.7 to 66.7 with eight instruments below 50. Regarding validity, the SOHO-5 (Fig. 2) and the Child Dental Pain Questionnaire (Child-DPQ) (Fig. 3) did not reach this threshold, while insufficient information was found for the IFAQ and DFTO (Fig. 3) to calculate this score. Only in half the instruments was it possible to calculate an EMPRO responsiveness score, as the information was insufficient in the other nine. Interpretability scores were high for 
ECOHIS (66.7 in Fig. 2), CPQ11-14 (88.9 in Fig. 3), FIS and POQL (77.8 and 66.7 in Fig. 4), below 50 for eight instruments, and it was not possible to calculate them for six instruments.

The interview-administration version of the CPQ11-14 and CPQ8-10, as well as versions for telephone interview-administration of CPQ11-14 and self-administration of Child-OIDP, obtained 83 points in the EMPRO evaluation of the 'Alternative forms of administration’ (Online Resource 4) because most metric properties were evaluated and scores were similar to those from the original administration versions. Similarly, short forms derived from Child Oral Health Impact Profile (Child-OHIP with 19 items), CPQ1114 (with 16 and 8 items), FIS (with 8 items) and P-CPQ (with 16 items) were well rated, with scores over 80. The DDQ, with 8 items, is the only short form which has not yet demonstrated suitable metric properties nor enough comparability with the original instrument scores. 


\section{DISCUSSION}

This review provides exhaustive information about the oral health-related quality of life instruments designed for preschoolers, schoolchildren, adolescents, and for the whole childhood and adolescence cycle, in order to facilitate an informed decision about the optimum instrument for a specific study according to metric properties and purpose of application. The most highly rated ones, according to the EMPRO tool's standard criteria, were the ECOHIS in preschoolers and the CPQ11-14 in schoolchildren. The FIS was shown to be an excellent instrument to measure the impact of oral health on the family. Results obtained by Child-OIDP and Child-OHIP in schoolchildren, as well as POQL and P-CPQ for any age, also make them recommendable. The SOHO-5 in preschoolers and CPQ8-10 in schoolchildren scored just above the threshold, indicating reasonably acceptable results, while instruments specific for malocclusion and hypodontia are only slightly below this.

In preschoolers, the five identified questionnaires showed generally an adequate process in their development and were valid; however, only the ECOHIS presented good reliability, responsiveness, and interpretability. SOHO-5, despite its high responsiveness (100 points), would need more research on reliability and interpretability. Furthermore, ECOHIS is the only questionnaire that has been culturally adapted to 14 languages or countries (allowing international studies), and has a section assessing the impact of oral problems on the family, making it the most complete instrument. Although ECOHIS and SOHO-5 were originally developed to assess the impact of dental caries, they have both been widely used to evaluate several oral pathologies [5,23] and are currently considered generic oral health-related quality of life instruments.

Among the nine instruments developed for schoolchildren and adolescents, the CPQ 11-14, Child-OIDP, and Child OHIP scored the highest in the overall EMPRO assessment, and also obtained good results for conceptual model, reliability, validity and responsiveness. Furthermore, the CPQ11-14 presented a high EMPRO score for interpretability (88.9), and has been validated for a number of dental and oro-facial pathologies, such as caries [24], enamel defects [25], dental fluorosis [26], malocclusion $[27,28]$ and craniofacial disorders [29,30]. Although the CPQ11-14 is long (37 items), its short versions (8 and 16 items) allow to minimize administration burden and facilitate its 
applicability. Unexpectedly, the CPQ 11-14 and the CPQ 8-10, developed by the same research group using the same strategy for each age stratum, presented substantially different EMPRO overall scores (82.1 vs 55.2). However, the worse results obtained by CPQ8-10 are mostly explained by the lack of studies on its interpretability, which penalizes substantially the overall EMPRO score since it is 1 of the 5 components. Finally, the two condition-specific instruments designed for malocclusion and hypodontia were well rated for conceptual model, reliability, and validity, but needed further research for responsiveness and interpretability

In children and adolescents of any age, the FIS, P-CPQ and POQL were those with the best EMPRO evaluation. However, it is important to remember that FIS measures the impact on the family, P-CPQ measures the impact on the child from the parent's perspective, and POQL has been validated only for dental caries. FIS and P-CPQ were developed for children between 6 and 14 years old, but their psychometric properties have been evaluated on children from 3 years of age onwards. Both instruments have derived short versions (8 and 16 items respectively) validated for several conditions, such as caries [31,32], oro-facial conditions [33,34], dental fluorosis [31] or orthodontic treatment [33,34], and have been adapted in 5 languages.

Our results are consistent with those reported by the previous systematic review [20] of Child-OIDP, Child-OHIP and P-CPQ showing acceptable evidence on validity. However, our EMPRO results in reliability, responsiveness and interpretability are more favorable for these instruments. These differences could be explained by the larger number of studies analyzed in our review than in theirs [20]: 54 studies vs 7 for CPQ11-14, 17 vs 2 for CPQ8-10, 21 vs 2 for Child-OIDP, and 16 vs 4 for Child OHIP. Furthermore, EMPRO uses several criteria covering different aspects of methods and the quality of the results for each evaluated attribute (from 3 criteria in responsiveness or interpretability to 7 in measurement model) [13]. The previous review, instead, synthesized the evaluation of each attribute's quality in a single criterion [14].

Age is a key issue in the assessment of patient-reported outcomes in children: it determines the direct or proxy sources of information, but also the way they experience oral health-related quality of life [35], which generates the need to develop instruments for each age strata. Only the PedsQL-OH has specific age versions [36] allowing to measure with 
the same instruments the whole childhood and adolescence cycle without missing agespecific information. Proxy reporting is the standard in preschoolers [35] due to their difficulties in fully comprehending and/or communicating their perceptions. In this sense, the self-reported versions of the SOHO-5, and Michigan-OHRQoL are especially valuable, providing the children's own perspective in preschoolers [37]. A SOHO-5 study [38] obtained similar oral health-related quality of life results from parents and their children. Children usually start abstract thinking and compare their physical features and personality traits with their peers at the age of six, which allows self-reporting from this age on [39]. In general, evidence shows that parents underestimate the impact of children's oral problems, since they have a different perspective and limited knowledge, particularly related to social and emotional well-being [40]. Oral health-related quality of life domains directly observable by parents, such as physical complaints and functionality, concur better with children's perceptions [41,42]. In this sense, it is noteworthy that self-reporting was chosen for all instruments identified for schoolchildren and adolescents in our review.

In general, specific instruments scored worse than generic instruments according to the EMPRO evaluation. Then again, their potential advantages for certain study purposes or populations makes them worthy of further comment. Condition-specific instruments for malocclusion and hypodontia, symptom-specific for pain (DDQ and Child-DPQ), and treatment-specific for fixed appliances (IFAQ) have in common not reporting any information on responsiveness and presenting poor results on interpretability. This is important for longitudinal studies and clinical trials, where responsiveness and reproducibility are key attributes, as it cannot be assumed that a measure shown to be reliable and valid in cross-sectional studies will necessarily be sensitive to changes over time in a clinical intervention. Therefore, if responsiveness is not demonstrated prior to its application, it is not sure whether this change is real or generated by measurement error $[43,44]$. On the other hand, developing strategies to facilitate the interpretation of scores (such as estimating the minimal important difference by using anchor-based or distributionbased strategies) may help to extend the use of these instruments. Finally, it is also noteworthy that the Dental Freetime Trade-Off (DFTO) scale is the only econometric instrument identified in our search, designed as a preference-based health index [45]. However, its poor results in our metric quality evaluation indicate the need of future 
research, mainly to confirm validity, reliability and responsiveness of the utilities for economic evaluation of oral health interventions.

The main strengths of this study are that the information regarding development process, metric properties, and administrative issues of oral health-related quality of life instruments in children and adolescents was obtained in a systematic review of the literature and was evaluated by experts using a standardized tool. The EMPRO combines two fundamental aspects: well-described and established criteria for the assessment of attributes, taking into account the quality of the methodology as well as the results obtained; and scores that allow for a direct comparison of attributes and overall performance among the evaluated instruments.

Our findings should be interpreted taking into account some limitations that deserve to be addressed. Firstly, we may have failed to identify all oral health-related quality of life instruments or relevant articles. However, to minimize this, we applied a sensitive search strategy, an additional hand search of references along with two online databases of patientreported outcomes, and a double independent review process. Secondly, the EMPRO evaluation is based on the quantity and quality of published evidence on each instrument. A lack of information for a few EMPRO items or attributes penalizes the EMPRO scores, because the scoring algorithm counts any missing information as the worst possible rating. Nevertheless, to minimize such penalization, the EMPRO score was not calculated if information on half or more items/attributes was missing. For example, IFAQ and DFTO reported information only for conceptual model and reliability; therefore their overall EMPRO score was not calculated. This should be interpreted as the need to produce such information before an evidence-based decision can be made. Thirdly, EMPRO ratings may be biased by evaluators. It is important to notice that, to avoid this bias, each item of the EMPRO tool includes a comprehensive description which facilitates rating standardization; and we carried out a double independent evaluation followed by a consensus, as in the majority of previous EMPRO studies $[46,16,17,47]$. Fourthly, selecting the cut-off point of 50 as the threshold to consider the EMPRO scores acceptable for any purpose and setting is questionable. This threshold was obtained with data from the first two EMPRO studies $[13,15]$ : the area under the Receiver Operating Characteristic (ROC) curve evaluating the agreement between EMPRO attribute scores and the reviewers' global recommendations 
was of 0.87 (data not shown but available upon request). Therefore, this cut-off point should be used only as a guide to identify potential gaps. Fifthly, studies on the metric properties of the original instrument and the country versions derived from it were considered in our EMPRO evaluation. These studies contribute with information and provide valuable data about the generalization of the instruments' psychometric data. Finally, although clinical trials can provide indirect evidence on some metric properties such as validity, sensitivity to change or interpretability, none were included in our study, because they were not specifically designed for the assessment of metric properties nor included this as a secondary objective.

\section{CONCLUSIONS}

This is the first study to provide a systematic and reliable expert-based evaluation of all available oral health-related quality of life instruments in preschoolers, schoolchildren and adolescents. Our results support the selection for preschoolers of the Early Childhood Oral Health Impact Scale (ECOHIS), or the Scale of Oral Health Outcomes for 5-year-old (SOHO-5) in the case of preferring the children reporting themselves. When evaluating schoolchildren and adolescents, the age of the target population is a key factor in choosing among the following recommended instruments: CPQ11-14, Child OIDP (11-15 years), Child-OHIP (8-15 years), or CPQ8-10. The administration of Child Perceptions Questionnaires (CPQ11-14 or CPQ8-10) together with Parental-Caregiver Perceptions Questionnaire (PCPQ) and Family Impact Scale (FIS) can provide a complete evaluation of the patient's oral health-related quality of life, by measuring both the parents' and children's perceptions and also the impact on the family. The Pediatric Oral Health-Related Quality of Life (POQL) is also recommended for ages 2-16 years, both with proxy and selfcompletion. However, the instruments designed to assess a specific condition, symptom or treatment, as well as the only questionnaire developed for economic evaluation, need further research on their metric properties before taking advantage of their specificity. Our results may facilitate the decision-making process regarding the correct instrument selection and its use for each study purpose. 


\section{ACKNOWLEDGEMENTS}

Carlos Zaror is a PhD candidate in Methodology of Biomedical Research and Public Health program, Universitat Autònoma de Barcelona, Barcelona, Spain.

$\mathrm{M}^{\mathrm{a}}$ José Martínez is funded by a Miguel Servet research contract from the Instituto de Salud Carlos III and European Social Fund (CP15/00116).

Montse Ferrer is partially funded by the Departament d'Innovació, Universitats i Empresa, Generalitat de Catalunya (2014 SGR 748).

We would like to acknowledge Aurea Martin for her help in the English editing process and figures edition of this manuscript.

\section{COMPLIANCE WITH ETHICAL STANDARDS}

Conflict of Interest: The authors declare that they have no conflict of interest.

Funding: This project was funded by a grant from the Convenio de Desempeño Regional, FRO 1301, Universidad de La Frontera Nº UNT15-0012.

Ethical approval: This article does not contain any studies with human participants or animals performed by any of the authors.

Informed consent: For this type of study, formal consent is not required. 


\section{REFERENCES}

1. Zaror C, Pineda P, Orellana J (2011) Prevalence of early childhood caries and associated factors in 2 and 4 year-old Chilean children. Int J Odontostomatol 5:171177

2. Aldrigui JM, Jabbar NS, Bonecker M, Braga MM, Wanderley MT (2014) Trends and associated factors in prevalence of dental trauma in Latin America and Caribbean: a systematic review and meta-analysis. Community Dent Oral Epidemiol 42:30-42. doi:10.1111/cdoe.12053

3. Do LG (2012) Distribution of caries in children: variations between and within populations. J Dent Res 91:536-543. doi:10.1177/0022034511434355

4. Kassebaum NJS, A.G.C.; Bernabé, E.; Fleming T.D.; Reynolds, A.E.; Vos, T.; Murray, C.J.L.; Marcenes, W. ; GBD 2015 Oral Health Collaborators (2017) Global, Regional, and National Prevalence, Incidence, and Disability-Adjusted Life Years for Oral Conditions for 195 Countries, 1990-2015: A Systematic Analysis for the Global Burden of Diseases, Injuries, and Risk Factors. J Dent Res 96:380-387

5. Abanto J, Carvalho TS, Mendes FM, Wanderley MT, Bonecker M, Raggio DP (2011) Impact of oral diseases and disorders on oral health-related quality of life of preschool children. Community Dent Oral Epidemiol 39:105-114. doi:10.1111/j.1600-0528.2010.00580.x

6. Antonarakis GS, Patel RN, Tompson B (2013) Oral health-related quality of life in non-syndromic cleft lip and/or palate patients: a systematic review. Community Dent Health 30:189-195

7. Bendo CB, Paiva SM, Varni JW, Vale MP (2014) Oral health-related quality of life and traumatic dental injuries in Brazilian adolescents. Community Dent Oral Epidemiol 42:216-223. doi:10.1111/cdoe.12078

8. Kragt L, Dhamo B, Wolvius EB, Ongkosuwito EM (2016) The impact of malocclusions on oral health-related quality of life in children-a systematic review and meta-analysis. Clin Oral Investig 20:1881-1894. doi:10.1007/s00784-015-16813 
9. Zaror C, Martinez-Zapata MJ, Abarca J, Diaz J, Pardo Y, Pont A, Ferrer M (2018) Impact of traumatic dental injuries on quality of life in preschoolers and schoolchildren: A systematic review and meta-analysis. Community Dent Oral Epidemiol 46:88-101. doi:10.1111/cdoe.12333

10. Zhou Y, Wang Y, Wang X, Voliere G, Hu R (2014) The impact of orthodontic treatment on the quality of life a systematic review. BMC Oral Health 14:66. doi:10.1186/1472-6831-14-66

11. Sischo L, Broder HL (2011) Oral health-related quality of life: what, why, how, and future implications. J Dent Res 90:1264-1270. doi:10.1177/0022034511399918

12. Aaronson N, Alonso J, Burnam A, Lohr KN, Patrick DL, Perrin E, Stein RE (2002) Assessing health status and quality-of-life instruments: attributes and review criteria. Qual Life Res 11:193-205

13. Valderas JM, Ferrer M, Mendivil J, Garin O, Rajmil L, Herdman M, Alonso J, Scientific Committee on "Patient-Reported Outcomes" of the IRYSS Network (2008) Development of EMPRO: a tool for the standardized assessment of patientreported outcome measures. Value Health 11:700-708. doi:10.1111/j.15244733.2007.00309.x

14. Mokkink LB, Terwee CB, Patrick DL, Alonso J, Stratford PW, Knol DL, Bouter LM, de Vet HC (2010) The COSMIN checklist for assessing the methodological quality of studies on measurement properties of health status measurement instruments: an international Delphi study. Qual Life Res 19:539-549. doi:10.1007/s11136-010-9606-8

15. Garin O, Herdman M, Vilagut G, Ferrer M, Ribera A, Rajmil L, Valderas JM, Guillemin F, Revicki D, Alonso J (2014) Assessing health-related quality of life in patients with heart failure: a systematic, standardized comparison of available measures. Heart Fail Rev 19:359-367. doi:10.1007/s10741-013-9394-7

16. Schmidt S, Ferrer M, Gonzalez M, Gonzalez N, Valderas JM, Alonso J, Escobar A, Vrotsou K, Group E (2014) Evaluation of shoulder-specific patient-reported outcome measures: a systematic and standardized comparison of available evidence. J Shoulder Elbow Surg 23:434-444. doi:10.1016/j.jse.2013.09.029 
17. Schmidt S, Garin O, Pardo Y, Valderas JM, Alonso J, Rebollo P, Rajmil L, GarciaForero C, Ferrer M, Group E (2014) Assessing quality of life in patients with prostate cancer: a systematic and standardized comparison of available instruments. Qual Life Res 23:2169-2181. doi:10.1007/s11136-014-0678-8

18. Gibbons CJ, Bee PE, Walker L, Price O, Lovell K (2014) Service user- and carerreported measures of involvement in mental health care planning: methodological quality and acceptability to users. Front Psychiatry 5:178. doi:10.3389/fpsyt.2014.00178

19. Maratia S, Cedillo S, Rejas J (2016) Assessing health-related quality of life in patients with breast cancer: a systematic and standardized comparison of available instruments using the EMPRO tool. Qual Life Res 25:2467-2480. doi:10.1007/s11136-016-1284-8

20. Gilchrist F, Rodd H, Deery C, Marshman Z (2014) Assessment of the quality of measures of child oral health-related quality of life. BMC Oral Health 14:40. doi:10.1186/1472-6831-14-40

21. Moher D, Liberati A, Tetzlaff J, Altman DG, Group P (2009) Preferred reporting items for systematic reviews and meta-analyses: the PRISMA statement. PLoS Med 6:e1000097. doi:10.1371/journal.pmed.1000097

22. Higgins JPT, Green S (editors) (2011). Cochrane Handbook for Systematic Reviews of Interventions Version 5.1.0. The Cochrane Collaboration. Available from www.handbook.cochrane.org.

23. Gomes MC, Pinto-Sarmento TC, Costa EM, Martins CC, Granville-Garcia AF, Paiva SM (2014) Impact of oral health conditions on the quality of life of preschool children and their families: a cross-sectional study. Health Qual Life Outcomes 12:55. doi:10.1186/1477-7525-12-55

24. Shin HS, Han DH, Shin MS, Lee HJ, Kim MS, Kim HD (2015) Korean version of child perceptions questionnaire and dental caries among Korean children. PloS One 10:e0116011. doi:10.1371/journal.pone.0116011

25. Marshman Z, Rodd H, Stern M, Mitchell C, Locker D, Jokovic A, Robinson PG (2005) An evaluation of the Child Perceptions Questionnaire in the UK. Community Dent Health 22:151-155 
26. Kumar S, Kroon J, Lalloo R, Johnson NW (2016) Psychometric Properties of Translation of the Child Perception Questionnaire (CPQ11-14) in Telugu Speaking Indian Children. PloS One 11:e0149181. doi:10.1371/journal.pone.0149181

27. O'Brien C, Benson PE, Marshman Z (2007) Evaluation of a quality of life measure for children with malocclusion. J Orthod 34:185-193. doi:10.1179/146531207225022185

28. O'Brien K, Wright JL, Conboy F, Macfarlane T, Mandall N (2006) The child perception questionnaire is valid for malocclusions in the United Kingdom. Am J Orthod Dentofacial Orthop 129:536-540. doi:10.1016/j.ajodo.2004.10.014

29. Jokovic A, Locker D, Stephens M, Kenny D, Tompson B, Guyatt G (2002) Validity and reliability of a questionnaire for measuring child oral-health-related quality of life. J Dent Res 81:459-463

30. Wogelius P, Gjorup H, Haubek D, Lopez R, Poulsen S (2009) Development of Danish version of child oral-health-related quality of life questionnaires (CPQ8-10 and CPQ11-14). BMC Oral Health 9:11. doi:10.1186/1472-6831-9-11

31. Kumar S, Kroon J, Lalloo R, Johnson NW (2016) Validity and reliability of short forms of parental-caregiver perception and family impact scale in a Telugu speaking population of India. Health Qual Life Outcomes 14:34. doi:10.1186/s12955-0160433-7

32. Marshman Z, Rodd H, Stem M, Mitchell C, Robinson PG (2007) Evaluation of the Parental Perceptions Questionnaire, a component of the COHQoL, for use in the UK. Community Dent Health 24 (4):198-204

33. Jokovic A, Locker D, Stephens M, Kenny D, Tompson B, Guyatt G (2003) Measuring parental perceptions of child oral health-related quality of life. J Public Health Dent 63:67-72

34. Locker D, Jokovic A, Stephens M, Kenny D, Tompson B, Guyatt G (2002) Family impact of child oral and oro-facial conditions. Community Dent Oral Epidemiol 30:438-448

35. Wallander JL, Schmitt M, Koot HM (2001) Quality of life measurement in children and adolescents: issues, instruments, and applications. J Clin Psychol 57:571-585 
36. Steele MM, Steele RG, Varni JW (2009) Reliability and Validity of the PedsQL Oral Health Scale: Measuring the relationship between child oral health and healthrelated quality of life. Child Health Care 38:228-244. doi:10.1080/02739610903038818

37. Piovesan C, Batista A, Ferreira F, Ardenghi TM (2009) Oral health-related quality of life in children: Conceptual issues. Rev Odonto Cienc 24 (1):81-85

38. Abanto J, Tsakos G, Paiva SM, Raggio DP, Celiberti P, Bonecker M (2014) Agreement between children aged 5-6 years and their mothers in rating child oral health-related quality of life. I Int J Paediatr Dent 24:373-379. doi:10.1111/ipd.12081

39. Barbosa TS, Gaviao MB (2008) Oral health-related quality of life in children: part I. How well do children know themselves? A systematic review. Int J Dent Hyg 6:9399. doi:10.1111/j.1601-5037.2007.00276.x

40. Barbosa TS, Gaviao MB (2008) Oral health-related quality of life in children: part III. Is there agreement between parents in rating their children's oral health-related quality of life? A systematic review. Int J Dent Hyg 6:108-113. doi:10.1111/j.16015037.2007.00271.x

41. Theunissen NC, Vogels TG, Koopman HM, Verrips GH, Zwinderman KA, Verloove-Vanhorick SP, Wit JM (1998) The proxy problem: child report versus parent report in health-related quality of life research. Qual Life Res 7:387-397

42. Reissmann DR, John MT, Sagheri D, Sierwald I (2016) Diagnostic accuracy of parents' ratings of their child's oral health-related quality of life. Qual Life Res 26:881-891. doi:10.1007/s11136-016-1427-y

43. Lee GH, McGrath C, Yiu CK, King NM (2011) Sensitivity and responsiveness of the Chinese ECOHIS to dental treatment under general anaesthesia. Community Dent Oral Epidemiol 39:372-377. doi:10.1111/j.1600-0528.2010.00604.x

44. Locker D, Jokovic A, Clarke M (2004) Assessing the responsiveness of measures of oral health-related quality of life. Community Dent Oral Epidemiol 32:10-18. doi:10.1111/j.1600-0528.2004.00114.X

45. Fyffe HE, Deery C, Nugent Z, Nuttall NM, Pitts NB (1999) The reliability of two methods of utility assessment in dentistry. Community Dent Health 16:72-79 
46. Khurana V, Sharma H, Afroz N, Callan A, Medin J (2017) Patient-reported outcomes in multiple sclerosis: a systematic comparison of available measures. Eur J Neurol 24:1099-1107. doi:10.1111/ene.13339

47. Sinclair S, Russell LB, Hack TF, Kondejewski J, Sawatzky R (2017) Measuring Compassion in Healthcare: a comprehensive and critical review. Patient 10:389405. doi:10.1007/s40271-016-0209-5

48. Versloot J, Veerkamp JS, Hoogstraten J (2004) Dental Discomfort Questionnaire: predicting toothache in preverbal children. Eur J Paediatr Dent 5:170-173

49. Pahel BT, Rozier RG, Slade GD (2007) Parental perceptions of children's oral health: the Early Childhood Oral Health Impact Scale (ECOHIS). Health Qual Life Outcomes 5:6. doi:10.1186/1477-7525-5-6

50. Filstrup SL, Briskie D, da Fonseca M, Lawrence L, Wandera A, Inglehart MR (2003) Early childhood caries and quality of life: child and parent perspectives. Pediatr Dent 25:431-440

51. Mathur VP, Dhillon JK, Logani A, Agarwal R (2014) Development and validation of oral health-related early childhood quality of life tool for North Indian preschool children. Indian J Dent Res 25:559-566. doi:10.4103/0970-9290.147078

52. Tsakos G, Blair YI, Yusuf H, Wright W, Watt RG, Macpherson LM (2012) Developing a new self-reported scale of oral health outcomes for 5-year-old children (SOHO-5). Health Qual Life Outcomes 10:62. doi:10.1186/1477-7525-1062

53. Barretto ER, Paiva SM, Pordeus IA, Ferreira e Ferreira E (2011) Validation of a child dental pain questionnaire instrument for the self-reporting of toothache in Children. Pediatr Dent 33:228-232

54. Broder HL, McGrath C, Cisneros GJ (2007) Questionnaire development: face validity and item impact testing of the Child Oral Health Impact Profile. Community Dent Oral Epidemiol 35 Suppl 1:8-19. doi:10.1111/j.16000528.2007.00401.x

55. Gherunpong S, Tsakos G, Sheiham A (2004) Developing and evaluating an oral health-related quality of life index for children; the CHILD-OIDP. Community Dent Health 21:161-169 
56. Jokovic A, Locker D, Tompson B, Guyatt G (2004) Questionnaire for measuring oral health-related quality of life in eight- to ten-year-old children. Pediatr Dent 26:512-518

57. Mandall NA, Vine S, Hulland R, Worthington HV (2006) The impact of fixed orthodontic appliances on daily life. Community Dent Health 23:69-74

58. Patel N, Hodges SJ, Hall M, Benson PE, Marshman Z, Cunningham SJ (2016) Development of the Malocclusion Impact Questionnaire (MIQ) to measure the oral health-related quality of life of young people with malocclusion: part 1 - qualitative inquiry. J Orthod 43:7-13. doi:10.1080/14653125.2015.1114712

59. Akram AJ, Jerreat AS, Woodford J, Sandy JR, Ireland AJ (2011) Development of a condition-specific measure to assess quality of life in patients with hypodontia. Orthod Craniofac Res 14:160-167. doi:10.1111/j.1601-6343.2011.01517.x

60. Huntington NL, Spetter D, Jones JA, Rich SE, Garcia RI, Spiro A, 3rd (2011) Development and validation of a measure of pediatric oral health-related quality of life: the POQL. J Public Health Dent 71:185-193 
Table 1: Summarized characteristics of instruments designed for preschoolers, in alphabetical order.

\begin{tabular}{|c|c|c|c|c|c|c|}
\hline Instrument & $\begin{array}{c}\text { Purpose of } \\
\text { Development } \\
\text { (Age) }\end{array}$ & $\begin{array}{c}\text { Administration } \\
\text { mode }\end{array}$ & $\begin{array}{c}\text { Dimensions } \\
\text { (No. of items) }\end{array}$ & $\begin{array}{c}\text { Response } \\
\text { options }\end{array}$ & $\begin{array}{l}\text { Scores } \\
\text { (range) }\end{array}$ & $\begin{array}{l}\text { Original } \\
\text { \& adapted } \\
\text { languages }\end{array}$ \\
\hline $\begin{array}{l}\text { 1.Dental Discomfort } \\
\text { Questionnaire (DDQ) } \\
\text { [48] }\end{array}$ & $\begin{array}{l}\text { Dental } \\
\text { Discomfort/ } \\
\text { Dental Pain } \\
\text { (2-5 years) }\end{array}$ & $\begin{array}{l}\text { Proxy- } \\
\text { administered }\end{array}$ & $\begin{array}{l}\text { Occurrence of } \\
\text { toothache (3) } \\
\text { Behavior associated } \\
\text { discomfort (12) }\end{array}$ & $\begin{array}{l}1^{\text {st }} \text { part: } 4-\text { point } \\
\text { Likert scale } \\
2^{\text {nd }} \text { part: } 3- \\
\text { point Likert } \\
\text { scale }\end{array}$ & $\begin{array}{l}\text { Global score } \\
(0-24)\end{array}$ & $\begin{array}{l}\text { English } \\
\text { Netherland } \\
\text { Portuguese }\end{array}$ \\
\hline $\begin{array}{l}\text { 2.Early Childhood } \\
\text { Oral Health Impact } \\
\text { Scale (ECOHIS) } \\
\text { [49] }\end{array}$ & $\begin{array}{l}\text { Oral diseases } \\
\text { (0-5 years) }\end{array}$ & $\begin{array}{l}\text { Proxy- } \\
\text { administered }\end{array}$ & \begin{tabular}{|l|} 
Symptom (1) \\
Function (4) \\
Psychology(2) \\
Social (2) \\
Parental distress (2) \\
Family function (2)
\end{tabular} & $\begin{array}{l}\text { 5-point Likert } \\
\text { scale }\end{array}$ & $\begin{array}{l}\text { Global score } \\
(0-52) \\
\text { Scores by } \\
\text { dimension }\end{array}$ & \begin{tabular}{|l} 
English \\
Chinese \\
Spanish \\
Portuguese \\
(Portugal, \\
Luanda) \\
French \\
Persian \\
Arabic \\
Turkish \\
Lithuanian \\
Kiswahili \\
Kannada \\
Malayalam \\
Malay
\end{tabular} \\
\hline $\begin{array}{l}\text { 3.Michigan Oral } \\
\text { Health-Related } \\
\text { Quality of Life } \\
\text { (Michigan-OHRQoL) } \\
\text { [50] }\end{array}$ & $\begin{array}{l}\text { Oral diseases } \\
\text { (1-5 years) }\end{array}$ & $\begin{array}{l}\text { Self- } \\
\text { administered } \\
\text { Proxy- } \\
\text { administered }\end{array}$ & $\begin{array}{l}\text { Unidimensional } \\
\text { Child version (9) } \\
\text { Parent version (10) }\end{array}$ & $\begin{array}{l}\text { Child version: } \\
\text { yes/no } \\
\text { Parent version: } \\
\text { 5-point Likert } \\
\text { scale }\end{array}$ & $\begin{array}{l}\text { No } \\
\text { information }\end{array}$ & English \\
\hline $\begin{array}{l}\text { 4.Oral Health-related } \\
\text { Early Childhood } \\
\text { Quality of Life } \\
\text { (OH-ECQOL) } \\
\text { [51] }\end{array}$ & $\begin{array}{l}\text { Oral diseases } \\
\text { (2-5 years) }\end{array}$ & \begin{tabular}{|l|} 
Proxy- \\
administered
\end{tabular} & $\begin{array}{l}\text { Unidimensional } \\
\text { - Child Impact (12) } \\
\text { - Family Impact (4) }\end{array}$ & $\begin{array}{l}\text { 3-point Likert } \\
\text { scale }\end{array}$ & \begin{tabular}{|l} 
Global score \\
$(16-48)$
\end{tabular} & Hindi \\
\hline $\begin{array}{l}\text { 5.Scale of Oral Health } \\
\text { Outcomes for 5-year- } \\
\text { old children } \\
\text { (SOHO-5) } \\
\text { [52] }\end{array}$ & $\begin{array}{l}\text { Oral diseases } \\
\text { (5 years) }\end{array}$ & $\begin{array}{l}\text { Self- } \\
\text { administered } \\
\text { Proxy- } \\
\text { administered }\end{array}$ & Unidimensional (7) & $\begin{array}{l}\text { Child version: } \\
\text { 3-point Likert } \\
\text { scale } \\
\\
\text { Parental } \\
\text { version 5-point } \\
\text { Likert scale }\end{array}$ & $\begin{array}{l}\text { Global Score } \\
\text { (Child } \\
\text { version 0-14) } \\
\text { (Parental } \\
\text { version 0-28) }\end{array}$ & $\begin{array}{l}\text { English } \\
\text { Portuguese } \\
\text { (Brazil) }\end{array}$ \\
\hline
\end{tabular}


Table 2: Summarized characteristics of instruments designed for schoolchildren and adolescents, in alphabetical order.

\begin{tabular}{|c|c|c|c|c|c|c|}
\hline Instrument & \begin{tabular}{|c|} 
Purpose of \\
Development \\
(Age)
\end{tabular} & $\begin{array}{c}\text { Administration } \\
\text { mode }\end{array}$ & $\begin{array}{l}\text { Dimensions } \\
\text { (No. of items) }\end{array}$ & $\begin{array}{c}\text { Response } \\
\text { options }\end{array}$ & $\begin{array}{l}\text { Scores } \\
\text { (range) }\end{array}$ & $\begin{array}{l}\text { Original } \\
\text { \& adapted } \\
\text { languages }\end{array}$ \\
\hline $\begin{array}{l}\text { 1. Child dental pain } \\
\text { questionnaire } \\
\text { (Child-DPQ) } \\
\text { [53] }\end{array}$ & $\begin{array}{l}\text { Dental pain } \\
\text { (8-9 years) }\end{array}$ & $\begin{array}{l}\text { Self- } \\
\text { administered }\end{array}$ & $\begin{array}{l}\text { Prevalence (2) } \\
\text { Severity (2) } \\
\text { Impact (2) }\end{array}$ & $\begin{array}{l}\text { Different } \\
\text { types of } \\
\text { responses }\end{array}$ & $\begin{array}{l}\text { Global score } \\
(0-15)\end{array}$ & English \\
\hline $\begin{array}{l}\text { 2.Child Oral Health } \\
\text { Impact Profile } \\
\text { (Child-OHIP) } \\
\text { [54] }\end{array}$ & $\begin{array}{l}\text { Oral diseases } \\
\text { (8-15 years) }\end{array}$ & $\begin{array}{l}\text { Self- } \\
\text { administered }\end{array}$ & \begin{tabular}{|l} 
Oral health (10) \\
Functional (6) \\
Social-emotional \\
Well-being (8) \\
School \\
environment (6) \\
Self-images (4) \\
\end{tabular} & $\begin{array}{l}\text { 5-point } \\
\text { Likert scale }\end{array}$ & $\begin{array}{l}\text { Global Score } \\
(34-170)\end{array}$ & \begin{tabular}{|l|} 
English \\
Persian \\
Dutch \\
Chinese \\
German \\
Korean \\
French \\
\end{tabular} \\
\hline $\begin{array}{l}\text { 3.Child-Oral Impact on } \\
\text { Daily Performance Index } \\
\text { (Child-OIDP) } \\
\text { [55] }\end{array}$ & $\begin{array}{l}\text { Oral diseases } \\
\text { (11-15 years) }\end{array}$ & $\begin{array}{l}\begin{array}{l}\text { Self- } \\
\text { administered }\end{array} \\
\text { Interviewer- } \\
\text { administered }\end{array}$ & $\begin{array}{l}\text { Physical (4) } \\
\text { Psychological } \\
\text { Social (4) }\end{array}$ & $\begin{array}{l}\text { 3-point } \\
\text { Likert scale }\end{array}$ & $\begin{array}{l}\text { Global Score } \\
(0-100)\end{array}$ & $10 *$ \\
\hline $\begin{array}{l}\text { 4.Child Perceptions } \\
\text { Questionnaire 8-10 } \\
\text { (CPQ8-10) } \\
\text { [56] }\end{array}$ & $\begin{array}{l}\text { Oral diseases } \\
\text { (8-10 years) }\end{array}$ & $\begin{array}{l}\text { Self- } \\
\text { administered } \\
\text { Interview } \\
\text { administered }\end{array}$ & $\begin{array}{l}\text { Oral symptoms (5) } \\
\text { Functional } \\
\text { limitations (5) } \\
\text { Emotional well- } \\
\text { being (5) } \\
\text { Social well-being } \\
(10)\end{array}$ & $\begin{array}{l}\text { 5-point } \\
\text { Likert scale }\end{array}$ & $\begin{array}{l}\text { Global Score } \\
(1-55)\end{array}$ & $\begin{array}{l}\text { English } \\
\text { Spanish } \\
\text { Portuguese } \\
\text { Bosnian } \\
\text { Cambodian } \\
\text { Danish } \\
\text { Korean } \\
\text { Japanese }\end{array}$ \\
\hline $\begin{array}{l}\text { 5.Child Perceptions } \\
\text { Questionnaire 11-14 } \\
\text { (CPQ11-14) } \\
\text { [29] }\end{array}$ & $\begin{array}{l}\text { Oral diseases } \\
\text { (11-14 years) }\end{array}$ & $\begin{array}{l}\text { Self- } \\
\text { administered } \\
\text { Interview } \\
\text { administered } \\
\text { Telephone } \\
\text { interview }\end{array}$ & $\begin{array}{l}\text { Oral symptoms (6) } \\
\text { Functional } \\
\text { limitations (9) } \\
\text { Emotional well- } \\
\text { being (9) } \\
\text { Social well- } \\
\text { being(13) }\end{array}$ & $\begin{array}{l}\text { 5-point } \\
\text { Likert scale }\end{array}$ & $\begin{array}{l}\text { Global Score } \\
(1-80)\end{array}$ & $12^{* *}$ \\
\hline $\begin{array}{l}\text { 6.Dental Freetime Trade- } \\
\text { Off scale (DFTO) } \\
\text { [45] }\end{array}$ & $\begin{array}{l}\text { Utility } \\
\text { (14-19 years) }\end{array}$ & $\begin{array}{l}\text { Self- } \\
\text { administered }\end{array}$ & Unidimensional (5) & $\begin{array}{l}\text { Different } \\
\text { types of } \\
\text { responses }\end{array}$ & $\begin{array}{l}\text { Global score } \\
\text { (minutes) }\end{array}$ & English \\
\hline $\begin{array}{l}\text { 7.Impact of Fixed } \\
\text { Appliances } \\
\text { Questionnaire (IFAQ) } \\
\text { [57] }\end{array}$ & \begin{tabular}{|l|} 
Fixed \\
orthodontic \\
appliances \\
(10-18 years) \\
\end{tabular} & $\begin{array}{l}\text { Self- } \\
\text { administered }\end{array}$ & No information & $\begin{array}{l}\text { 5-point } \\
\text { Likert scale }\end{array}$ & $\begin{array}{l}\text { Global score } \\
(0-34)\end{array}$ & English \\
\hline $\begin{array}{l}\text { 8.Malocclusion Impact } \\
\text { Questionnaire (MIQ) } \\
\text { [58] }\end{array}$ & $\begin{array}{l}\text { Malocclusion } \\
\text { (10-16 years) }\end{array}$ & $\begin{array}{l}\text { Self- } \\
\text { administered }\end{array}$ & $\begin{array}{l}\text { Appearance of } \\
\text { teeth } \\
\text { Effect on social } \\
\text { interactions } \\
\text { Oral health and } \\
\text { function } \\
\text { Global (28) } \\
\end{array}$ & $\begin{array}{l}\text { 3-point } \\
\text { Likert scale }\end{array}$ & $\begin{array}{l}\text { Global score } \\
(0-64)\end{array}$ & English \\
\hline $\begin{array}{l}\text { 9.Oral Health Related } \\
\text { Quality of Life for } \\
\text { patients with Hypodontia } \\
\text { (OHRQoL Hypodontia) } \\
\text { [59] }\end{array}$ & \begin{tabular}{|l|} 
Hypodontia- \\
Anodontia \\
(11-18 years)
\end{tabular} & $\begin{array}{l}\text { Self- } \\
\text { administered }\end{array}$ & No information & $\begin{array}{l}\text { No } \\
\text { information }\end{array}$ & $\begin{array}{l}\text { No } \\
\text { information }\end{array}$ & \begin{tabular}{|l|} 
English \\
\end{tabular} \\
\hline
\end{tabular}


Table 3: Summarized characteristics of instruments designed for the whole childhood and adolescence cycle

\begin{tabular}{|c|c|c|c|c|c|c|}
\hline Instrument & $\begin{array}{c}\text { Purpose of } \\
\text { Development } \\
\text { (Age) }\end{array}$ & $\begin{array}{c}\text { Administration } \\
\text { mode }\end{array}$ & $\begin{array}{c}\text { Dimensions } \\
\text { (No. of items) }\end{array}$ & $\begin{array}{l}\text { Response } \\
\text { options }\end{array}$ & $\begin{array}{l}\text { Scores } \\
\text { (range) }\end{array}$ & $\begin{array}{l}\text { Original } \\
\text { \& adapted } \\
\text { languages } \\
\end{array}$ \\
\hline $\begin{array}{l}\text { 1.Family Impact Scale } \\
\text { (FIS) } \\
\text { [34] }\end{array}$ & $\begin{array}{l}\text { Family impact } \\
\text { Oral disease } \\
(2-14 \text { years) }\end{array}$ & $\begin{array}{l}\text { Proxy- } \\
\text { administered }\end{array}$ & $\begin{array}{l}\text { Parental/family } \\
\text { activity (5) } \\
\text { Parental emotions } \\
\text { (4) } \\
\text { Family conflict (4) } \\
\end{array}$ & $\begin{array}{l}\text { 5-point } \\
\text { Likert scale }\end{array}$ & $\begin{array}{l}\text { Global score } \\
(0-33)\end{array}$ & $\begin{array}{l}\text { English } \\
\text { Portuguese } \\
\text { Chinese } \\
\text { Telugu }\end{array}$ \\
\hline $\begin{array}{l}\text { 2.Parental-Caregiver } \\
\text { Perceptions } \\
\text { Questionnaire (P-CPQ) } \\
\text { [33] }\end{array}$ & $\begin{array}{l}\text { Oral diseases } \\
\text { (2-14 years ) }\end{array}$ & $\begin{array}{l}\text { Proxy- } \\
\text { administered }\end{array}$ & $\begin{array}{l}\text { Oral symptoms (6) } \\
\text { Functional } \\
\text { limitations (8) } \\
\text { Emotional well- } \\
\text { being (7) } \\
\text { Social well- } \\
\text { being(10) }\end{array}$ & $\begin{array}{l}\text { 5-point } \\
\text { Likert scale }\end{array}$ & $\begin{array}{l}\text { Global score } \\
(0-124)\end{array}$ & $\begin{array}{l}\text { English } \\
\text { Spanish } \\
\text { Portuguese } \\
\text { Chinese } \\
\text { Telugu }\end{array}$ \\
\hline $\begin{array}{l}\text { 3.Pediatric Quality of } \\
\text { Life Inventory } \\
\text { Health Scale Oral } \\
\text { (PedsQL }^{\mathrm{TM}} \text { Oral Health } \\
\text { Scale } \\
{[36]}\end{array}$ & $\begin{array}{l}\text { Oral diseases } \\
\text { (2-18 years) }\end{array}$ & $\begin{array}{l}\text { Self- } \\
\text { administered } \\
\text { Proxy- } \\
\text { administered }\end{array}$ & Unidimensional (5) & $\begin{array}{l}\text { 5-point } \\
\text { Likert scale }\end{array}$ & $\begin{array}{l}\text { Global score } \\
(0-100)\end{array}$ & $\begin{array}{l}\text { English } \\
\text { Portuguese } \\
\text { (Brazil) } \\
\text { Persian }\end{array}$ \\
\hline $\begin{array}{l}\text { 4.Pediatric Oral Health- } \\
\text { Related Quality of Life } \\
\text { (POQL) } \\
\text { [60] }\end{array}$ & $\begin{array}{l}\text { Oral diseases } \\
\text { (2-16 years) }\end{array}$ & $\begin{array}{l}\text { Self- } \\
\text { administered } \\
\text { Proxy- } \\
\text { administered }\end{array}$ & $\begin{array}{l}\text { Physical } \\
\text { functioning } \\
\text { Role functioning } \\
\text { Emotional impact } \\
\text { Social impact } \\
\text { Global (10) }\end{array}$ & $\begin{array}{l}4 \text { and 5- } \\
\text { point Likert } \\
\text { scale }\end{array}$ & $\begin{array}{l}\text { Global score } \\
(0-100)\end{array}$ & $\begin{array}{l}\text { English } \\
\text { Spanish }\end{array}$ \\
\hline
\end{tabular}




\section{FIGURE LEGENDS}

Fig. 1. Flowchart of the systematic literature review, instruments identified. [Total number of articles per instrument (articles evaluating cross-cultural versions in brackets)].

Fig. 2. Overall EMPRO ranking and attribute-specific scores of instruments designed for preschoolers (Age 0-6 years).

Figure legend: The grey line on 50 (half of the 100 maximum theoretical points) represents the reasonably acceptable cut-off defined for EMPRO scores.

Abbreviations: Dental Discomfort Questionnaire (DDQ), Early Childhood Oral Health Impact Scale (ECOHIS), Michigan oral health-related QoL scale (Michigan-OHRQoL), Oral Health-related Early Childhood Quality of Life tool (OH-ECQOL), and Scale of Oral Health Outcomes for 5-year-old children (SOHO-5).

Fig. 3. Overall EMPRO ranking and attribute-specific scores of instruments designed for schoolchildren and adolescents (Age 7-18 years).

Figure legend: The grey line on 50 (half of the 100 maximum theoretical points) represents the reasonably acceptable cut-off defined for EMPRO scores.

Abbreviations: Child Dental Pain Questionnaire (Child-DPQ), Child Oral Health Impact Profile (Child-OHIP), Child-Oral Impact on Daily Performance Index (Child-OIDP), Child Perceptions Questionnaire 8-10 (CPQ8-10), Child Perceptions Questionnaire 11-14 (CPQ11-14), Dental Freetime Trade-Off Scale (DFTO), Impact of Fixed Appliances Questionnaire (IFAQ), Malocclusion Impact Questionnaire (MIQ), and Oral Health-Related Quality of Life for patients with Hypodontia (OHRQoL Hypodontia).

Fig. 4. Overall EMPRO ranking and attribute-specific scores of instruments designed for children and adolescents (Age 0-18 years)

Figure legend: The grey line on 50 (half of the 100 maximum theoretical points) represents the reasonably acceptable cut-off defined for EMPRO scores.

Abbreviations: Family Impact Scale (FIS), Parental-Caregiver Perceptions Questionnaire (P-CPQ), Pediatric Oral Health-Related Quality of Life (POQL), and Pediatric Quality of Life Inventory ${ }^{\mathrm{TM}}$ Oral Health Scale ${ }^{\mathrm{TM}}$ (PedsQL-OH ${ }^{\mathrm{TM}}$ ). 


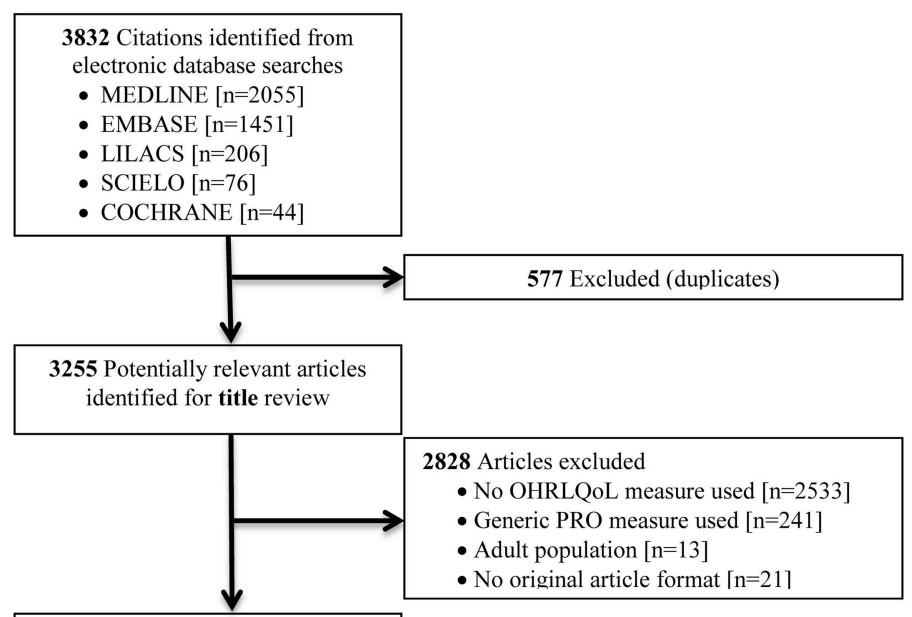

427 Potentially relevant articles identified for abstract review

281 Articles excluded

- Article without metric property

information [ $\mathrm{n}=203]$

- Generic PRO measure used [ $\mathrm{n}=19]$

- Adult population [n=38]

- No original article format [n=18]

- Language not included [n=3]

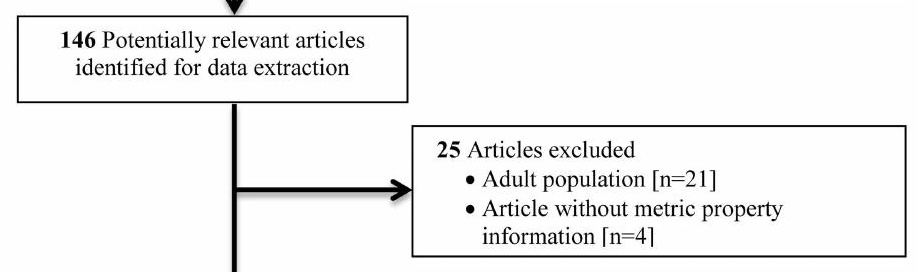

11 Articles included after identification by hand-search and online databases of PRO

\section{Preschoolers (Age 0-5)}

- DDQ [n=7 (2)]

- ECOHIS [n=27 (22)]

- Michigan $\mathrm{OH}[\mathrm{n}=1]$

- OH-ECQOL [n=1]

- SOHO-5 [n=5 (4)]

132 Articles identified and used in the EMPRO evaluation

(18 Instruments)
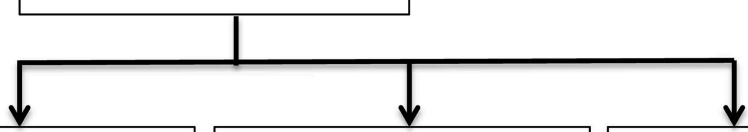

\section{Schoolchildren and} Adolescents (Age 6-18)

- Child-DPQ [n=1]

- Child-OHIP [n=16 (6)]

- Child-OIDP[n=21 (14)]

- CPQ8-10 [n=17 (16)]

- CPQ11-14 [n=54 (46)]

- $\operatorname{DFTO}[\mathrm{n}=1]$

- IFAQ [n=1]

- MIQ [n=2]

- OHRQoL Hypodontia [n=2] 
Overall Score

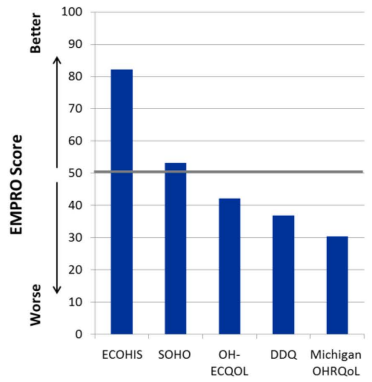

\section{Reliability}

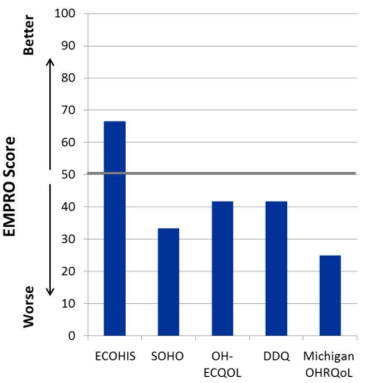

Responsiveness

인

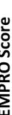$$
\text { ڤั) }
$$

Conceptual and measurement model

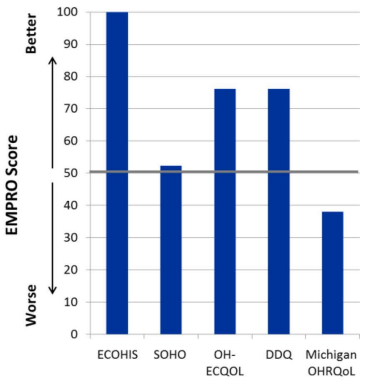

\section{Validity}

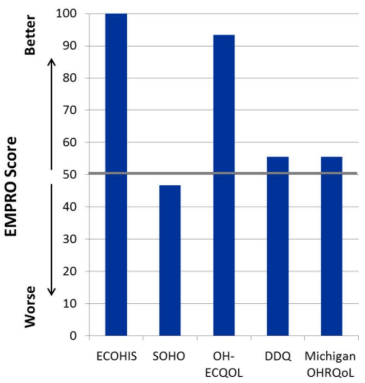

Interpretability

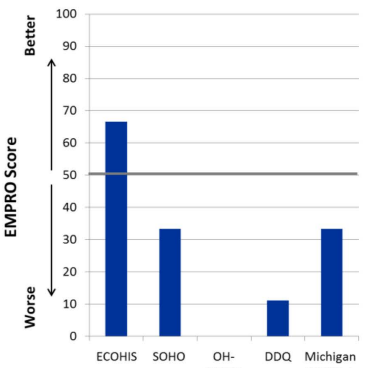



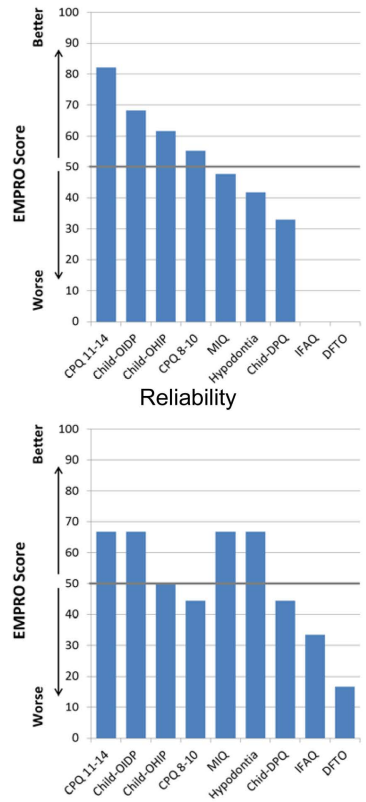

Responsiveness
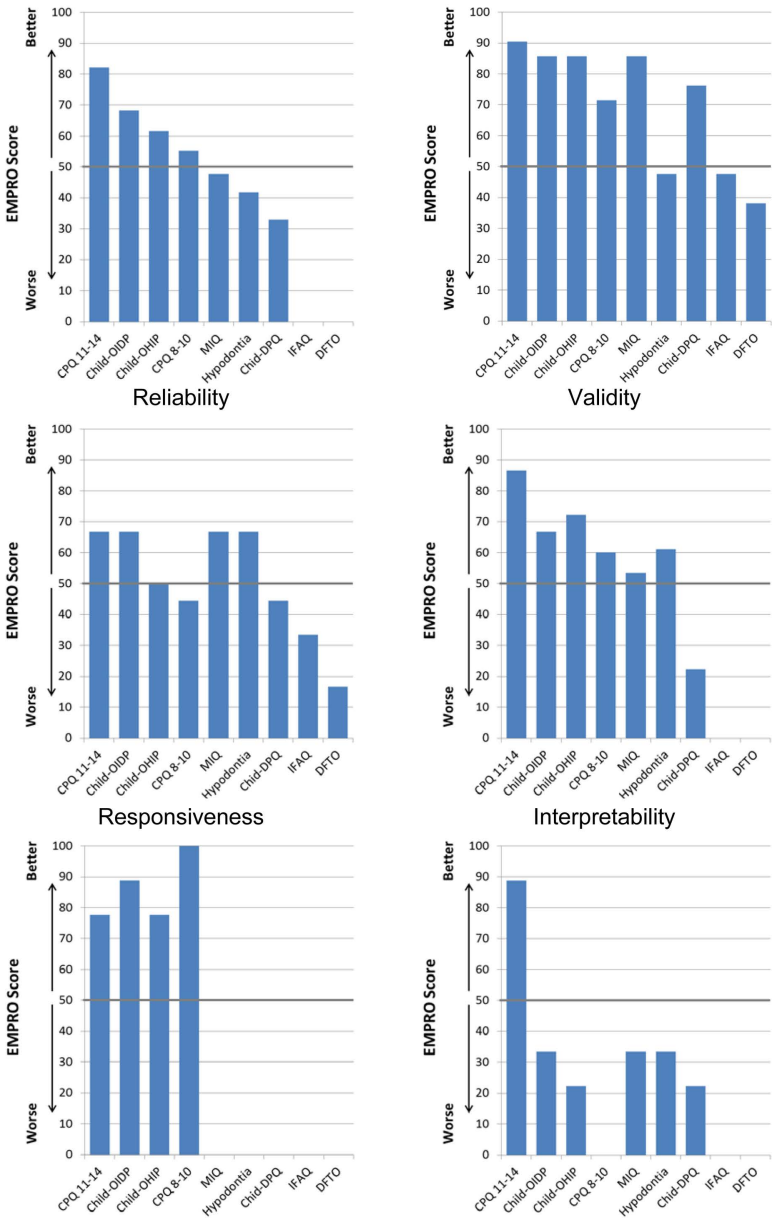


\section{Overall Score}

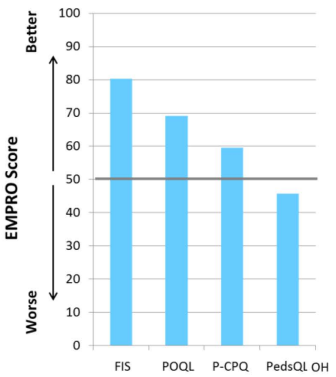

Reliability

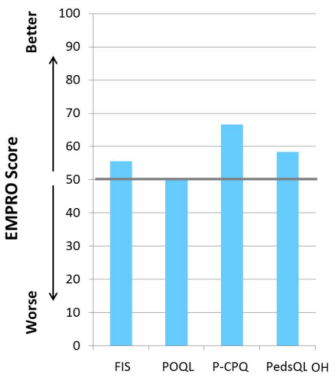

Responsiveness

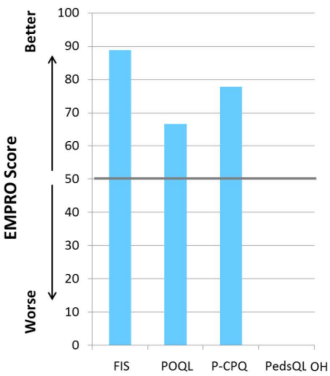

Conceptual and measurement model
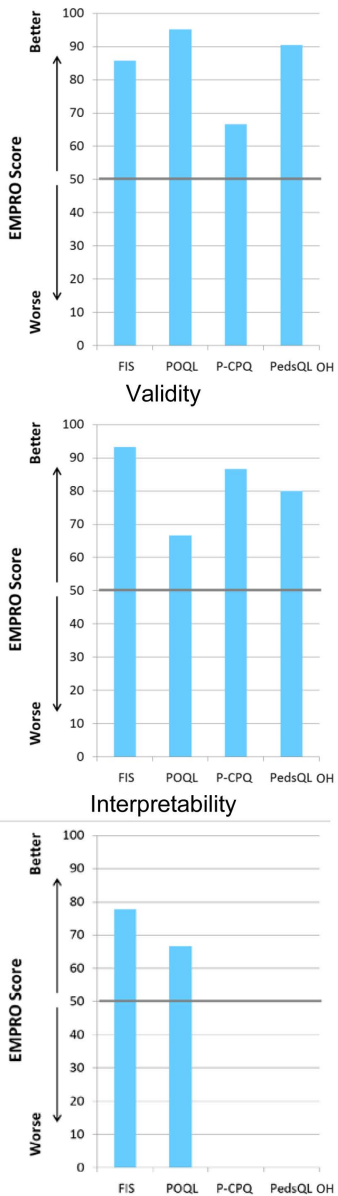


\section{Supplement 1: Search strategy on MEDLINE}

(((()((()((()((()(((Validation Studies[pt]) OR Psychometrics[mh]) OR Questionnaires[mh]) OR feasibility[tiab]) OR instrument[tiab]) OR instruments[tiab]) OR item*[tiab]) OR index[ti]) OR measure[tiab]) OR measures[tiab]) OR questionnaire*[ti]) OR scale[ti]) OR scales[ti]) OR reliability[tiab]) OR validation[tiab]) OR validity[tiab]) OR "Cross-Cultural Comparison"[Mesh])) AND (((((((((“Quality of Life”[MeSH]) OR Quality of life[tiab]) OR HRQoL[tiab]) OR QoL[tiab]) OR QALY[tiab]) OR utility[tiab]) OR disability[tiab]) OR "Disability Evaluation"[Mesh]) OR "Quality-Adjusted Life Years"[Mesh]))) AND (((()((()((()(“Oral Health”[MeSH]) OR “Dental Caries”[MeSH]) OR oral[tiab]) OR caries[tiab]) OR orofacial[tiab]) OR dental[tiab]) OR periodontal[tiab]) OR gingivitis[tiab]) OR maxillofacial[tiab]) OR temporomandibular[tiab]) OR tooth[tiab]) OR teeth[tiab]) OR "Periodontal Diseases"[Mesh]) OR "Tooth"[Mesh]) OR "Maxillofacial Injuries"[Mesh])) AND (((c((()((“Child”[MeSH]) OR “Infant”[MeSH]) OR “Adolescent”[MeSH]) OR “Pediatrics”[MeSH]) OR “Pediatric Dentistry”[MeSH]) OR pediatric*[tiab]) OR paediatric*[tiab]) OR infant*[tiab]) OR child*[tiab]) OR teen*[tiab]) OR adolescent*[tiab]) 


\section{PRESCHOOLER (AGE 0-5)}

\section{Dental Discomfort Questionnaire (DDQ)}

1. Daher A, Versloot J, Costa LR (2014) The cross-cultural process of adapting observational tools for pediatric pain assessment: the case of the Dental Discomfort Questionnaire. BMC Res Notes 7:897.

2. Daher A, Versloot J, Leles CR, Costa LR (2014). Screening preschool children with toothache: validation of the Brazilian version of the Dental Discomfort Questionnaire. Health Qual. Life Outcomes 12:30.

3. Versloot J, Hall-Scullin E, Veerkamp JSJ, Freeman R (2008) Dental discomfort questionnaire: its use with children with a learning disability. Spec Care Dent 28:140-144.

4. Versloot J, Veerkamp J, Hoogstraten J (2006) Dental Discomfort Questionnaire: assessment of dental discomfort and/or pain in very young children Community Dent Oral Epidemiol 34:47-52.

5. Versloot J, Veerkamp JS, Hoogstraten J (2004) Dental Discomfort Questionnaire: predicting toothache in preverbal children. Eur J Paediatr Dent 5:170-173.

6. Versloot J, Veerkamp JSJ, Hoogstraten J (2005) Dental discomfort questionnaire for young children before and after treatment. Acta Odontol Scand 63:367-70.

7. Versloot J, Veerkamp JSJ, Hoogstraten J (2006) Dental Discomfort Questionnaire for young children following full mouth rehabilitation under general anaesthesia: a follow-up report. Eur Arch Paediatr Dent. 7:126-9.

\section{Early Childhood Oral Health Impact Scale (ECOHIS)}

1. Abanto J, Paiva SM, Sheiham A, Tsakos G, Mendes FM, Cordeschi T, Vidigal EA, Bönecker M (2016) Changes in preschool children's OHRQoL after treatment of dental caries: responsiveness of the B-ECOHIS. Int J Paediatr Dent 26:259-265.

2. Arrow P (2016). Responsiveness and sensitivity of the Early Childhood Oral Health Impact Scale to primary dental care for early childhood caries. Community Dent Oral Epidemiol 44:1-10.

3. Arrow P, Klobas E (2015) Evaluation of the Early Childhood Oral Health Impact Scale in an Australian preschool child population. Aust Dent J 60:375-381.

4. Bhat SG, Sivaram R (2015) Psychometric properties of the Malayalam version of ECOHIS. J Indian Soc Pedod Prev Dent 33:234-238.

5. Bordoni N, Ciaravino O, Zambrano O, Villena R, Beltran-Aguilar E, Squassi A (2012) Early Childhood Oral Health Impact Scale (ECOHIS). Translation and validation in Spanish language. Acta Odontol Latinoam 25:270-278.

6. Du RY, McGrath C, Yiu CKY, King NM (2010) Health- and oral health-related quality of life among preschool children with cerebral palsy. Qual Life Res 19:1367-1371.

7. Fernandes I, Ramos-Jorge J, Ramos-Jorge M, Bönecker M, Abanto J, Marques L, Paiva S (2015) Correlation and comparative analysis of discriminative validity of the Scale of Oral Health Outcomes for Five-Year-Old Children (SOHO-5) and the Early Childhood Oral Health Impact Scale (ECOHIS) for dental caries. BMC Oral Health 15:29.

8. Hashim AN, Yusof ZYM, Esa R (2015) The Malay version of the Early Childhood Oral Health Impact Scale (Malay-ECOHIS) - assessing validity and reliability. Health Qual Life Outcomes 13:190.

9. Jabarifar S-E, Golkari A, Ijadi MH, Jafarzadeh M, Khadem P (2010) Validation of a Farsi version of the early childhood oral health impact scale (F-ECOHIS). BMC Oral Health 10:4-11. 
10. Jankauskiene B, Narbutaite J, Kubilius R, Gleiznys A (2012) Adaptation and validation of the early childhood oral health impact scale in Lithuania. Stomatol Balt Dent Maxillofac J 14:108-113.

11. Lee GHM, McGrath C, Yiu CKY, King NM (2009) Translation and validation of a Chinese language version of the Early Childhood Oral Health Impact Scale (ECOHIS). Int J Paediatr Dent 19:399-405.

12. Lee GHM, McGrath C, Yiu CKY, King NM (2010) A comparison of a generic and oral health-specific measure in assessing the impact of early childhood caries on quality of life. Community Dent Oral Epidemiol 38:333-339.

13. Lee GHM, McGrath C, Yiu CKY, King NM (2011) Sensitivity and responsiveness of the Chinese ECOHIS to dental treatment under general anaesthesia. Community Dent Oral Epidemiol 39:372-377.

14. Li S, Malkinson S, Veronneau J, Allison PJ (2008) Testing responsiveness to change for the early childhood oral health impact scale (ECOHIS). Community Dent Oral Epidemiol. 36:542-548.

15. Li S, Veronneau J, Allison PJ (2008) Validation of a French language version of the Early Childhood Oral Health Impact Scale (ECOHIS). Health Qual Life Outcomes 6:9-15.

16. López Ramos RP, García Rupaya CR, Villena-Sarmiento R, Bordoni NE (2013) Cross cultural adaptation and validation of the Early Childhood Health Impact Scale (ECOHIS) in Peruvian preschoolers. Acta odontológica Latinoam. 26:60-67.

17. Martins-Júnior PA, Ramos-Jorge J, Paiva SM, Marques LS, Ramos-Jorge ML (2012) Validations of the Brazilian version of the Early Childhood Oral Health Impact Scale (ECOHIS). Cad Saude Publica 28:367-374.

18. Masumo R, Bardsen A, Mashoto K, Astrom AN (2012) Child- and family impacts of infants' oral conditions in Tanzania and Uganda- a cross sectional study. BMC Res Notes 5:538-547.

19. Pahel B, Rozier RG, Slade G (2007) Parental perceptions of children's oral health: The Early Childhood Oral Health Impact Scale (ECOHIS). Health Qual Life Outcomes 5:6-15.

20. Pani SC, Badea L, Mirza S, Elbaage N (2012) Differences in perceptions of early childhood oral health-related quality of life between fathers and mothers in Saudi Arabia. Int J Paediatr Dent 22:244-249.

21. Peker K, Uysal Ö, Bermek G. (2011) Cross - cultural adaptation and preliminary validation of the Turkish version of the early childhood oral health impact scale among 5-6-year-old children. Health Qual Life Outcomes 9:118.

22. Scarpelli AC, Oliveira BH, Tesch FC, Leão AT, Pordeus I a, Paiva SM (2011) Psychometric properties of the Brazilian version of the Early Childhood Oral Health Impact Scale (B-ECOHIS). BMC Oral Health 11:19.

23. Tesch FC, de Oliveira BH, Leão A (2008) Equivalência semântica da versão em português do instrumento Early Childhood Oral Health Impact Scale Semantic equivalence of the Brazilian version of the Early Childhood Oral Health Impact Scale. Cad Saude Publica 24:1897-1909.

24. Thomson WM, Foster Page L a, Malden PE, Gaynor WN, Nordin N (2014) Comparison of the ECOHIS and short-form P-CPQ and FIS scales. Health Qual Life Outcomes 12:36.

25. Wong HM, McGrath CPJ, King NM (2011) Rasch validation of the early childhood oral health impact scale. Community Dent Oral Epidemiol. 39:449-457.

26. Worsley DJ, Marshman Z, Robinson PG, Jones K (2016) Evaluation of the telephone and clinical NHS urgent dental service in Sheffield. Community Dent Health 33:9-14.

27. Yawary R, Anthonappa RP, Ekambaram M, McGrath C, King NM (2016) Changes in the oral health-related quality of life in children following comprehensive oral rehabilitation under general anaesthesia. Int J Paediatr Dent 26:322-329. 


\section{Michigan Oral health related QoL scale (Michigan- OHRQoL)}

1. Filstrup S, Dan B, Marcio da F, Leslie L, Angela W, Marita I (2003) Early Childhood Caries and Quality of Life: Child and Parent Perspectives. Pediatr Dent 25:431-40.

\section{Oral Health - related Early Childhood Quality of Life (OH- ECQOL)}

1. Mathur VP, Dhillon JK, Logani A, Agarwal R (2014) Development and validation of oral health-related early childhood quality of life tool for North Indian preschool children. Indian J Dent Res 25:559-566.

\section{Scale of Oral Health Outcomes for 5-year-old children (SOHO-5)}

1. Abanto J, Tsakos G, Ardenghi TM, Paiva SM, Raggio DP, Sheiham A, Bönecker M (2013) Responsiveness to change for the Brazilian Scale of Oral Health Outcomes for 5-year-old children (SOHO-5). Health Qual Life Outcomes 11:1-7.

2. Abanto J, Tsakos G, Paiva SM, Goursand D, Raggio DP, Bönecker M (2013) Cross-cultural adaptation and psychometric properties of the Brazilian version of the scale of oral health outcomes for 5-year-old children (SOHO-5). Health Qual Life Outcomes 11:11-16.

3. Alvarez JHA (2012) Adaptação transcultural, propriedades psicométricas e aplicação da versão brasileira do SOHO-5, instrumento de qualidade de vida relacionada à saúde bucal para crianças de 5 anos de idade. Dissertation, Universidade de Sao Paulo

4. Fernandes I, Ramos-Jorge J, Ramos-Jorge M, Bönecker M, Abanto J, Marques L, Paiva S (2015) Correlation and comparative analysis of discriminative validity of the Scale of Oral Health Outcomes for Five-Year-Old Children (SOHO-5) and the Early Childhood Oral Health Impact Scale (ECOHIS) for dental caries. BMC Oral Health 15:29.

5. Tsakos G, Blair YI, Yusuf H, Wright W, Watt RG, Macpherson LMD (2012) Developing a new self-reported scale of oral health outcomes for 5-year-old children (SOHO-5). Health Qual. Life Outcomes 10:62. 


\section{SCHOOLCHILDREN AND ADOLESCENTS (AGE 6-18)}

\section{Child dental pain questionnaire (Child-DPQ)}

1. Barrêtto ER, Paiva SM, Pordeus IA, Ferreira e Ferreira E (2011) Validation of a child dental pain questionnaire instrument for the self-reporting of toothache in Children. Pediatr Dent 33:228-32.

\section{Child Oral Health Impact Profile (Child-OHIP)}

1. Asgari I, Ahmady AE, Broder H, Eslamipour F, Wilson-Genderson M (2013) Assessing the oral health-related quality of life in Iranian adolescents: validity of the Persian version of the Child Oral Health Impact Profile (COHIP). Oral Health Prev Dent. 11:147-54.

2. Bos A, Hoogstraten J, Zentner A (2010) Perceptions of Dutch orthodontic patients and their parents on oral health-related quality of life. Angle Orthod. 80:367-372.

3. Broder H, Wilson-genderson M (2007) Reliability and convergent and discriminant validity of the Child Oral Health Impact Profile (COHIP Child 's version). Community Dent Oral Epidemiol 35:20-31.

4. Broder HL, McGrath C, Cisneros GJ (2007) Questionnaire development: Face validity and item impact testing of the child oral health impact profile. Community Dent Oral Epidemiol 35:8-19.

5. Broder HL, Norman RG, Sischo L, Wilson-Genderson M (2014) Evaluation of the similarities and differences in response patterns to the pediatric quality of life inventory and the child oral health impact scores among youth with cleft. Qual Life Res. 23:339-347.

6. Broder HL, Wilson-Genderson M, Sischo L (2012) Reliability and validity testing for the Child Oral Health Impact Profile-Reduced (COHIP-SF 19). J Public Health Dent. 72:302-312.

7. Cho Y Il, Lee S, Patton LL, Kim H-Y (2016) Confirmatory factor analysis of the Child Oral Health Impact Profile (Korean version). Eur J Oral Sci 124:172-178.

8. Dunlow N, Phillips C, Broder HL (2007) Concurrent validity of the COHIP. Community Dent Oral Epidemiol 35:41-49.

9. Geels LM, Hoogstraten J, Prahl-Andersen B (2008) Confirmative factor analysis of the dimensions of the Child Oral Health Impact Profile (Dutch version). Eur J Oral Sci. 116:148-152.

10. Kragt L, Tiemeier H, Wolvius EB, Ongkosuwito EM (2016) Measuring oral healthrelated quality of life in orthodontic patients with a short version of the Child Oral Health Impact Profile (COHIP). J Public Health Dent. 76:105-112.

11. Li C, Xia B, Wang Y, Guan X, Yuan J, Ge L (2014) Translation and psychometric properties of the Chinese (Mandarin) version of the Child Oral Health Impact Profile-Short Form 19 (COHIP-SF 19) for school-age children. Health Qual Life Outcomes 12:3.

12. El Osta N, Pichot H, Soulier-Peigue D, Hennequin M, Tubert-Jeannin S (2015) Validation of the child oral health impact profile (COHIP) french questionnaire among 12 years-old children in New Caledonia. Health Qual Life Outcomes 13:176.

13. Ruff RR, Sischo L, Broder HL (2016) Minimally important difference of the Child Oral Health Impact Profile for children with orofacial anomalies. Health Qual Life Outcomes 14:140.

14. Sierwald I, John MT, Sagheri D, Neuschulz J, Sch??ler E, Splieth C, JostBrinkmann PG, Reissmann DR (2016) The German 19-item version of the Child Oral Health Impact Profile: translation and psychometric properties. Clin Oral Investig. 20:301-313.

15. Wilson-Genderson M, Broder HL, Phillips C (2007) Concordance between caregiver and child reports of children's oral health-related quality of life. Community Dent Oral Epidemiol. 35:32-40.

16. Worsley DJ, Marshman Z, Robinson PG, Jones K (2016) Evaluation of the telephone and clinical NHS urgent dental service in Sheffield. Community Dent Health 33:9-14. 


\section{Child-Oral Impact on Daily Performance Index (Child-OIDP)}

1. Basavaraj P, Sunil MK, Nagarajappa R, Ashish S, Ramesh G (2014) Correlation between oral health and Child-OIDP index in 12- and 15-year-old children from Modinagar, India. Asia-Pacific J Public Health. 26:390-400.

2. Bernabé E, Krisdapong S, Sheiham A, Tsakos G (2009) Comparison of the discriminative ability of the generic and condition-specific forms of the Child-OIDP index: A study on children with different types of normative dental treatment needs. Community Dent Oral Epidemiol. 37:155-162.

3. Bernabé E, Sheiham A, Tsakos G (2008) A comprehensive evaluation of the validity of Child-OIDP: Further evidence from Peru. Community Dent Oral Epidemiol. 36:317-325.

4. Castro R a L, Cortes MIS, Leão AT, Portela MC, Souza IPR, Tsakos G, Marcenes W, Sheiham A (2008) Child-OIDP index in Brazil: cross-cultural adaptation and validation. Health Qual Life Outcomes 6:68-75.

5. Cortés-Martinicorena FJ, Rosel-Gallardo E, Artázcoz-Osés J, Bravo M, Tsakos G (2010) Adaptation and validation for Spain of the child-oral impact on daily performance (C-OIDP) for use with adolescents. Med Oral Patol Oral Cir Bucal 15:e106-11.

6. Gherunpong S, Sheiham A, Tsakos G (2006) A sociodental approach to assessing children' $s$ oral health needs : integrating an oral health-related quality of life (OHRQoL) measure into oral health service planning. Bull World Health Organ. 84:36-42.

7. Gherunpong S, Tsakos G, Sheiham A (2006). A sociodental approach to assessing dental needs of children: concept and models. Int J paedriatic Dent 16:81-88.

8. Gherunpong S, Tsakos G, Sheiham A. (2006). A socio-dental approach to assessing children's orthodontic needs. Eur J Orthod. 28:393-399.

9. Gherupong S, Tsakos G, Sheiham A (2004) Developing and evaluating an oral health-related quiality of life index for children; The CHILD-OIDP. Community Dent Health. 21:161-169.

10. Krisdapong S, Sheiham A (2014) Which aspects of an oral health-related quality of life measure are mainly associated with global ratings of oral health in children? Community Dent Oral Epidemiol. 42:129-138.

11. Mashoto KO, Astrøm AN, Skeie MS, Masalu JR (2010) Changes in the quality of life of Tanzanian school children after treatment interventions using the ChildOIDP. Eur J Oral Sci. 118:626-634.

12. Mtaya M, Astrøm AN, Tsakos G (2007 Applicability of an abbreviated version of the Child-OIDP inventory among primary schoolchildren in Tanzania. Health Qual. Life Outcomes 5:40-50.

13. Nurelhuda NM, Ahmed MF, Trovik TA, Åstrøm AN (2010) Evaluation of oral health-related quality of life among Sudanese schoolchildren using Child-OIDP inventory. Health Qual Life Outcomes 8:152-163.

14. Rosel E, Tsakos G, Bernabé E, Sheiham A, Bravo M (2010) Assessing the level of agreement between the self- and interview-administered Child-OIDP. Community Dent Oral Epidemiol. 38:340-347.

15. Tsakos G, Bernabé E, O’Brien K, Sheiham A, de Oliveira C (2008.) Comparison of the self-administered and interviewer-administered modes of the child-OIDP. Health Qual Life Outcomes 6:40.

16. Tsakos G, Gherunpong S, Sheiham A (2006) Can oral health-related quality of life measures substitute for normative needs assessments in 11 to 12 -year-old children? J. Public Health Dent 66:263-268.

17. Tubert-Jeanin S, Pegon-Machat E, Gremeau-Richard C, M-M L, Tsakos G (2005) Validation of the French version of the Child-OIDP index. Eur J Oral Sci 113:355362.

18. Vera C, Moreno X, Adaptation RD, Oral C (2013) Adaptation and validation of Child Oral Impact on Daily Performance index in 11- 14-year-old Chilean school children . ORIGINAL ARTICLE. J Oral Res 2:119-124. 
19. Worsley DJ, Marshman Z, Robinson PG, Jones K (2016) Evaluation of the telephone and clinical NHS urgent dental service in Sheffield. Community Dent Health 33:9-14.

20. Yusof ZYM, Jaafar N (2012) A Malay version of the Child Oral Impacts on Daily Performances (Child-OIDP) index: assessing validity and reliability. Health Qual Life Outcomes 10:63.

21. Yusuf H, Gherunpong S, Sheiham A, Tsakos G (2006) Validation of an English version of the Child-OIDP index, an oral health-related quality of life measure for children. Health Qual Life Outcomes 4:38.

\section{Child Perceptions Questionnaire 8-10 (CPQ8-10)}

1. Aguilar-Díaz F del C, Irigoyen-Camacho ME (2011) Validation of the CPQ 810ESP in Mexican schoolchildren in urban areas. Med Oral Patol Oral Cir. Bucal 16:430-435.

2. Barbosa T de S, Gavião MBD (2011) Qualidade de vida e saúde bucal em crianças parte II: versão brasileira do Child Perceptions Questionnaire Quality of life and oral health in children - Part II: Brazilian version of the Child Perceptions Questionnaire. Ciênc saúde coletiva 16:4077-4085.

3. Barbosa TDS, Gavião MBD (2015) Validation of the Parental-Caregiver Perceptions Questionnaire: Agreement between parental and child reports. J Public Health Dent 75:255-264.

4. Barbosa TS, Tureli MCM, Gavião MBD (2009) Validity and reliability of the Child Perceptions Questionnaires applied in Brazilian children. BMC Oral Health 9:1322.

5. Do LG, Spencer AJ (2008) Evaluation of oral health-related quality of life questionnaires in a general child population. Community Dent Health 25:205-210.

6. Foster Page L a, Boyd D, Thomson WM (2013) Do we need more than one Child Perceptions Questionnaire for children and adolescents? BMC Oral Health 13:26.

7. Hadzipasic-Nazdrajic A (2012) Validation of the Child Perceptions Questionnaire 8-10 in Bosnia and Herzegovina. Mater Socio Medica 24:157-161.

8. Humphris G, Freeman R, Gibson B, Simpson K, Whelton H (2005) Oral healthrelated quality of life for 8-10-year-old children: an assessment of a new measure. Community Dent Oral Epidemiol 33:326-332.

9. Jokovic A, Locker D, Tompson B, Guyatt G (2004) Questionnaire for Measuring Oral Health-related Quality of Life in Eight- to Ten-year-old Children. Pediatr. Dent. 26:512-518.

10. Martins MT, Ferreira FM, Oliveira AC, Paiva SM, Vale MP, Allison PJ, Pordeus IA (2009) Preliminary validation of the Brazilian version of the Child Perceptions Questionnaire 8-10. Eur J Paediatr Dent 10:135-140.

11. de Paula JS, Sarracini KLM, Meneghim MC, Pereira AC, Ortega EMM, Martins NS, Mialhe FL (2015) Longitudinal evaluation of the impact of dental caries treatment on oral health-related quality of life among schoolchildren. Eur J Oral Sci 123:173-178.

12. Ramos-Jorge ML, Vieira-Andrade RG, Martins-Júnior PA, Cordeiro MMR, RamosJorge J, Paiva SM, Marques LS (2012) Level of agreement between selfadministered and interviewer-administered CPQ 8-10 and CPQ 11-14. Community Dent Oral Epidemiol 40:201-209.

13. Shin HS, Han DH, Shin MS, Lee HJ, Kim MS, Kim HD (2015) Korean version of child perceptions questionnaire and dental caries among korean children. PLoS One 10:3-8.

14. Tellez M, Martignon S, Zuluaga J, Barreiro L, Builes L, Córdoba D, Gomez J (2010) Correlación de un Instrumento de Calidad de Vida relacionado con Salud Oral entre niños de 8 a 10 años y sus acudientes en Bogotá. Rev CES Odontol 23:9_ 15.

15. Turton BJ, Thomson WM, Foster Page L a, Saub RB, Razak IA (2013) Validation of an Oral Health-Related Quality of Life Measure for Cambodian Children. AsiaPacific J Public Health 27:2339-49 
16. Wogelius P, Gjørup H, Haubek D, Lopez R, Poulsen S (2009) Development of Danish version of child oral-health-related quality of life questionnaires (CPQ8-10 and CPQ11-14). BMC Oral Health 9:11.

17. Yamada H, Miura H, Usui Y, Sato T (2013) Development of the Japanese version of the Child Perceptions Questionnaire (CPQ8-10_JP). Pediatr Dent J 23:86-90.

\section{Child Perceptions Questionnaire 11-14 (CPQ11-14)}

1. Abanto J, Albites U, Bönecker M, Martins-Paiva S, Castillo JL, Aguilar-Gálvez D. (2013) Cross-cultural adaptation and psychometric properties of the child perceptions questionnaire 11-14 (CPQ11-14) for the peruvian spanish language. Med Oral Patol Oral Cir Bucal 18:1-7.

2. Agou S, Malhotra M, Tompson B, Prakash P, Locker D (2008) Is the child oral health quality of life questionnaire sensitive to change in the context of orthodontic treatment? A brief communication. J Public Health Dent 68:246-248

3. Barbosa T de S, Gavião MBD (2011) Qualidade de vida e saúde bucal em crianças parte II: versão brasileira do Child Perceptions Questionnaire Quality of life and oral health in children - Part II: Brazilian version of the Child Perceptions Questionnaire. Ciênc Saúde Coletiva 16:4077-4085.

4. Barbosa TDS, Gavião MBD (2015) Validation of the Parental-Caregiver Perceptions Questionnaire: Agreement between parental and child reports. J Public Health Dent 75:255-264.

5. Barbosa TS, Tureli MCM, Gavião MBD (2009) Validity and reliability of the Child Perceptions Questionnaires applied in Brazilian children. BMC Oral Health 9:1322.

6. Bekes K, John MT, Schaller H-GG, Hirsch C (2011) The German version of the child perceptions questionnaire on oral health-related quality of life (CPQ-G11-14): population-based norm values. J Orofac Orthop 72:223-33.

7. Bekes K, John MT, Zyriax R, Schaller HG, Hirsch C (2012) The German version of the Child Perceptions Questionnaire (CPQ-G11-14): Translation process, reliability, and validity in the general population. Clin Oral Investig 16:165-171.

8. Benson P, O’Brien C, Marshman Z (2010) Agreement between mothers and children with malocclusion in rating children's oral health-related quality of life. Am J Orthod Dentofac Orthop 137:631-8.

9. Bhayat A, Ali MAM (2014) Validity and reliability of the Arabic short version of the child oral health-related quality of life questionnaire (CPQ 11-14) in Medina, Saudi Arabia. East Mediterr Health J 20:477-482.

10. Brosens V, Ghijselings I, Lemiere J, Fieuws S, Clijmans M, Willems G (2014) Changes in oral health-related quality of life reports in children during orthodontic treatment and the possible role of self-esteem: A follow-up study. Eur J Orthod 36:186-191.

11. Brown A, Al-Khayal Z (2006) Validity and reliability of the Arabic translation of the child oral-health-related quality of life questionnaire (CPQ11-14) in Saudi Arabia Int J Paediatr Dent 16:405-411.

12. Del Carmen Aguilar-Díaz F, Foster Page LA, Thomson NM, Borges-Yáñez SA (2013) Differential item functioning of the Spanish version of the Child Perceptions Questionnaire. J Investig Clin Dent 4:34-38.

13. Ferreira MC, Goursand D, Bendo CB, Ramos-Jorge ML, Pordeus IA, Paiva SM (2012) Agreement between adolescents' and their mothers' reports of oral healthrelated quality of life. Braz Oral Res 26:112-8.

14. Foster Page L a, Boyd D, Thomson WM (2013) Do we need more than one Child Perceptions Questionnaire for children and adolescents? BMC Oral Health 13:26.

15. Foster Page L a, Thomson WM, Jokovic a, Locker D (2005) Validation of the Child Perceptions Questionnaire (CPQ 11-14). J Dent Res 84:649-652.

16. Foster Page LA, Thomson WM, Jokovic A, Locker D (2008) Epidemiological evaluation of short-form versions of the Child Perception Questionnaire. Eur J Oral Sci 116:538-544. 
17. Franz LN, Clericus RR, Bravo-Cavicchioli D, Del Río PJ, Gonzalez CF, Delgado GM. 2015. Adaptacion y validacion al Español del cuestionario de percepcion infantil CPQ-11-14 en población comunitaria Chilena. Rev Esp Salud Publica 89:585-595.

18. Ghijselings I, Brosens V, Willems G, Fieuws S, Clijmans M, Lemiere J (2014) Normative and self-perceived orthodontic treatment need in 11- to 16-year-old children. Eur J Orthod 36:179-185.

19. Goursand D, Paiva SM, Zarzar PM, Ramos-Jorge ML, Cornacchia GM, Pordeus I, Allison PJ (2008) Cross-cultural adaptation of the Child Perceptions Questionnaire 11-14 (CPQ11-14) for the Brazilian Portuguese language. Health Qual Life Outcomes 6:2-8.

20. Gururatana O, Baker SR, Robinson PG (2014) Determinants of children's oralhealth-related quality of life over time. Community Dent Oral Epidemiol. 42:206215.

21. Jokovic A, Locker D, Guyatt G (2004) How well do parents know their children? implications for proxy reporting of child health-related quality of life. Qual Life Res 13:1297-1307.

22. Jokovic A, Locker D, Guyatt G (2005) What do children's global rating of oral health and well being measure? Community Dent Oral Epidemiol 33:205-211.

23. Jokovic A, Locker D, Guyatt G (2006) Short forms of the Child Perceptions Questionnaire for 11-14-year-old children (CPQ11-14): development and initial evaluation. Heal Qual Life Outcomes 4:4-12.

24. Jokovic A, Locker D, Stephens M, Guyatt G (2003) Agreement between mothers and children aged 11-14 years in rating child oral health-related quality of life. Community Dent Oral Epidemiol 31:335-343.

25. Jokovic A, Locker D, Stephens M, Kenny D, Tompson B, Guyatt G (2002) Validity and reliability of a questionnaire for measuring child oral-health-related quality of life. J Dent Res 81:459-463.

26. Kok Y V, Mageson P, Harradine NWT, Sprod AJ (2004) Comparing a quality of life measure and the Aesthetic Component of the Index of Orthodontic Treatment Need (IOTN) in assessing orthodontic treatment need and concern. J Orthod 31:312-318.

27. Kumar S, Kroon J, Lalloo R, Johnson NW (2016) Psychometric properties of translation of the Child perception questionnaire (CPQ11-14) in Telugu speaking Indian children. PLoS One 11:1-10.

28. Lau AWH, Wong MCM, Lam KF, McGrath C (2009) Confirmatory factor analysis on the health domains of the child perceptions questionnaire. Community Dent Oral Epidemiol. 37:163-170.

29. Locker D (2008) Validity of single-item parental ratings of child oral health. Int J Paediatr Dent 18:407-414.

30. Locker D, Jokovic A, Tompson B, Prakash P (2007) Is the child perceptions questionnaire for 11-14 year olds sensitive to clinical and self-perceived variations in orthodontic status? Community Dent Oral Epidemiol 35:179-185.

31. Malter S, Hirsch C, Reissmann DR, Schierz O, Bekes K (2015) Effects of method of administration on oral health-related quality of life assessment using the Child Perceptions Questionnaire (CPQ-G11-14). Clin Oral Investig 19:1939-1945.

32. Marshman Z, Gibson BJ, Benson PE (2010) Is the short-form Child Perceptions Questionnaire meaningful and relevant to children with malocclusion in the UK? J Orthod. 37:29-36.

33. Marshman Z, Rodd H, Stern M, Mitchell C, Locker D, Jokovic A, Robinson PG (2005) An evaluation of the Child Perceptions Questionnaire in the UK. Community Dent Health 22:151-155.

34. McGrath C, Pang HN, Lo ECM, King NM, Hägg U, Samman N (2008) Translation and evaluation of a Chinese version of the child oral health-related quality of life measure. Int J Paediatr Dent 18:267-274.

35. O’Brien C, Benson PE, Marshman Z (2007) Evaluation of a quality of life measure for children with malocclusion. J Orthod 34:185-193. 
36. O’Brien K, Wright JL, Conboy F, Macfarlane T, Mandall N (2006) The child perception questionnaire is valid for malocclusions in the United Kingdom. Am J Orthod Dentofac Orthop 129:536-540.

37. Olivieri A, Ferro R, Benacchio L, Besostri A, Stellini E (2013) Validity of Italian version of the Child Perceptions Questionnaire (CPQ11-14). BMC Oral Health $13: 55$

38. Page L a F, Thomson WM, Mohamed R, Traebert J (2011) Performance and crosscultural comparison of the short-form version of the CPQ11-14 in New Zealand, Brunei and Brazil. Health Qual Life Outcomes 9:40-45.

39. Paula JS, Meneghim MC, Pereira AC, Mialhe FL (2015) Oral health, socioeconomic and home environmental factors associated with general and oral-health related quality of life and convergent validity of two instruments. BMC Oral Health $15: 26$.

40. Ramos-Jorge ML, Vieira-Andrade RG, Martins-Júnior PA, Cordeiro MMR, RamosJorge J, Paiva SM, Marques LS (2012) Level of agreement between selfadministered and interviewer-administered CPQ 8-10 and CPQ 11-14. Community Dent Oral Epidemiol. 40:201-209.

41. Salinas-Martínez AM, Hernández-Elizondo RT, Núñez-Rocha GM, Ramos Peña EG. 2014. Psychometric properties of the Spanish version of the short-form Child Perceptions Questionnaire for 11-14-year-olds for assessing oral health needs of children. J Public Health Dent 74:168-174.

42. Shin HS, Han DH, Shin MS, Lee HJ, Kim MS, Kim HD (2015) Korean version of child perceptions questionnaire and dental caries among korean children. PLoS One 10:3-8.

43. Thomson WM, Foster Page LA, Robinson PG, Do LG, Traebert J, Mohamed AR, Turton BJ, McGrath C, Bekes K, Hirsch C, et al. (2016) Psychometric assessment of the short-form Child Perceptions Questionnaire: an international collaborative study. Community Dent Oral Epidemiol 44:549-556.

44. Torres CS, Paiva SM, Vale MP, Pordeus IA, Ramos-Jorge ML, Oliveira AC, Allison PJ (2009) Psychometric properties of the Brazilian version of the Child Perceptions Questionnaire (CPQ11-14) - short forms. Health Qual Life Outcomes $7: 43$.

45. Traebert J, Foster Page L a, Thomson WM, Locker D (2010) Differential item functioning related to ethnicity in an oral health-related quality of life measure. Int $\mathrm{J}$ Paediatr Dent 20:435-441.

46. Traebert J, Lacerda JT De, Thomson WM, Page LF, Locker D (2010) Differential item functioning in a Brazilian-Portuguese version of the Child Perceptions Questionnaire (CPQ11-14). Community Dent Oral Epidemiol 38:129-135.

47. Turton BJ, Thomson WM, Foster Page L a, Saub RB, Razak IA (2013) Validation of an Oral Health-Related Quality of Life Measure for Cambodian Children. AsiaPacific J Public Health 27:1-11.

48. Turton BJ, Thomson WM, Foster Page LA, Saub R, Ishak AR (2015) Responsiveness of the child perceptions questionnaire 11-14 for cambodian children undergoing basic dental care. Int J Paediatr Dent 25:2-8.

49. Wogelius P, Gjørup H, Haubek D, Lopez R, Poulsen S (2009) Development of Danish version of child oral-health-related quality of life questionnaires (CPQ8-10 and CPQ11-14). BMC Oral Health 9:11.

50. Wong MCM, Lau AWH, Lam KF, McGrath C, Lu HX (2011) Assessing consistency in oral health-related quality of life (OHRQoL) across gender and stability of OHRQoL over time for adolescents using Structural Equation Modeling. Community Dent Oral Epidemiol. 39:325-335.

51. Worsley DJ, Marshman Z, Robinson PG, Jones K (2016) Evaluation of the telephone and clinical NHS urgent dental service in Sheffield. Community Dent Health 33:9-14.

52. Yau DTW, Wong MCM, Lam KF, McGrath C (2015) Evaluation of psychometric properties and differential item functioning of 8-item Child Perceptions Questionnaires using item response theory. BMC Public Health 15:792. 
53. Zhang M, McGrath C, Hägg U (2007) Who knows more about the impact of malocclusion on children's quality of life, mothers or fathers? Eur J Orthod 29:180185.

54. Zhang M, McGrath C, Hägg U (2008) Changes in oral health-related quality of life during fixed orthodontic appliance therapy. Am J Orthod Dentofac Orthop 133:2529.

\section{Dental freetime trade scale (DFTO)}

1. Fyffe HE, Deery C, Nugent Z, Nuttall NM, Pitts NB (1999) The reliability of two methods of utility assessment in dentistry. Community Dent Health 16:72-79.

\section{Impact of Fixed Appliances Questionnaire (IFAQ)}

1. Mandall NA, Vine S, Hulland R, Worthington H V (2006) The impact of fixed orthodontic appliances on daily life. Community Dent Health 23:69-74.

\section{Malocclusion Impact Questionnaire (MIQ)}

1. Patel N, Hodges SJ, Hall M, Benson PE, Marshman Z, Cunningham SJ (2016) Development of the Malocclusion Impact Questionnaire (MIQ) to measure the oral health-related quality of life of young people with malocclusion: part 1 - qualitative inquiry. J Orthod 43:7-13.

2. Benson PE, Cunningham. SJ, Shah N, Gilchrist F, Baker SR, Hodges SJ, Marshman Z (2016) Development of the Malocclusion Impact Questionnaire (MIQ) to measure the oral health-related quality of life of young people with malocclusion: part 2 cross-sectional validation. J Orthod 43:14-23.

\section{Oral Health Related Quality of Life for patients with Hypodontia (OHRQoL-Hypodontia)}

1. Akram AJ, Ireland AJ, Postlethwaite KC, Sandy JR, Jerreat AS (2013) Assessment of a condition-specific quality-of-life measure for patients with developmentally absent teeth: Validity and reliability testing. Orthod Craniofacial Res 16(4):193201.

2. Akram AJ, Jerreat AS, Woodford J, Sandy JR, Ireland AJ (2011) Development of a condition-specific measure to assess quality of life in patients with hypodontia. Orthod Craniofac Res 14:160-7. 


\section{CHILDREN AND ADOLESCENTS (AGE 0-18)}

\section{Family Impact Scale (FIS)}

1. Agou S, Malhotra M, Tompson B, Prakash P, Locker D (2008) Is the child oral health quality of life questionnaire sensitive to change in the context of orthodontic treatment? A brief communication. J Public Health Dent 68:246-248.

2. Baghdadi ZD (2014) Effects of dental rehabilitation under general anesthesia on children's oral health-related quality of life using proxy short versions of OHRQoL instruments. Sci World J 2014:308439

3. Barbosa T de S, Gaviao MBD (2009) Evaluation of the Family Impact Scale for use in Brazil. J Appl Oral Sci 17:397-403.

4. Goursand D, Paiva SM, Zarzar PM, Pordeus IA, Allison PJ (2009) Family Impact Scale (FIS): psychometric properties of the Brazilian Portuguese language version. Eur J Paediatr Dent 10:141-146.

5. Kumar S, Kroon J, Lalloo R, Johnson NW (2016) Validity and reliability of short forms of parental-caregiver perception and family impact scale in a Telugu speaking population of India. Health Qual Life Outcomes 14:34.

6. Locker D, Jokovic A, Stephens M, Kenny D, Tompson B, Guyatt G (2002) Family impact of child oral and oro-facial conditions. Community Dent Oral Epidemiol 30:438-448.

7. Malden PE, Thomson WM, Jokovic A, Locker D (20089 Changes in parentassessed oral health-related quality of life among young children following dental treatment under general anaesthetic. Community Dent Oral Epidemiol 36:108-117.

8. McGrant C, Pang HN, Lo ECM, King NM, Hägg U, Samman N (2008) Translation and evaluation of a Chinese version of the child oral health-related quality of life measure. Int J Paediatr Dent 18:267-274

9. Thomson WM, Foster Page L a, Malden PE, Gaynor WN, Nordin N (2014) Comparison of the ECOHIS and short-form P-CPQ and FIS scales. Health Qual Life Outcomes 12:36

10. Thomson WM, Foster Page LA, Gaynor WN, Malden PE (2013) Short-form versions of the Parental-Caregivers Perceptions Questionnaire and the Family Impact Scale. Community Dent Oral Epidemiol 41(5):441-450

\section{Parental-Caregiver Perceptions Questionnaire (P-CPQ)}

1. Agou S, Malhotra M, Tompson B, Prakash P, Locker D (2008) Is the child oral health quality of life questionnaire sensitive to change in the context of orthodontic treatment? A brief communication. J Public Health Dent 68:246-248.

2. Albites U, Abanto J, Bonecker M, Paiva S-M, Aguilar-Galvez D, Castillo J-L (2014) Parental-caregiver perceptions of child oral health-related quality of life (PCPQ): Psychometric properties for the Peruvian Spanish language. Med Oral Patol Oral y Cir Bucal 19:e220-e224.

3. Alves LA, Luiz RR, Thomé AT, Maia LC (2012) Initial assessment of responsiveness of the P-CPQ (Brazilian Version) to describe the changes in quality of life after treatment for traumatic dental injury. Dent Traumatol 28:256-62.

4. Baghdadi ZD (2014) Effects of dental rehabilitation under general anesthesia on children's oral health-related quality of life using proxy short versions of OHRQoL instruments. Sci World J 2014: 308439

5. Barbosa T de S, Steiner-Oliveira C, Gavião MBD (2010) Tradução e Adaptação Brasileira do Parental- Caregiver Perceptions Questionnaire ( P-CPQ ). Saúde Soc São Paulo 19:698-708.

6. Barbosa TDS, Gavião MBD. 2015. Validation of the Parental-Caregiver Perceptions Questionnaire: Agreement between parental and child reports. J Public Health Dent 75:255-264.

7. Benson P, O’Brien C, Marshman Z (2010) Agreement between mothers and children with malocclusion in rating children's oral health-related quality of life. Am J Orthod Dentofac Orthop 137:631-8. 
8. Ferreira MC1, Goursand D, Bendo CB, Ramos-Jorge ML, Pordeus IA, Paiva SM (2012) Agreement between adolescents' and their mothers' reports of oral health related quality of life. Braz Oral Res 26:112-119.

9. Do LG, Spencer AJ (2008) Evaluation of oral health-related quality of life questionnaires in a general child population. Community Dent Health 25:205-210.

10. Goursand D, Ferreira MC, Pordeus I a, Mingoti S a, Veiga RT, Paiva SM (2013) Development of a short form of the Brazilian Parental-Caregiver Perceptions Questionnaire using exploratory and confirmatory factor analysis. Qual Life Res 22:393-402.

11. Goursand D, Paiva SM, Zarzar PM, Pordeus IA, Grochowki R, Allison PJ (2009) Measuring Parental-Caregiver Perceptions of Child Oral Health-Related Quality of Life : Psychometric Properties of the Brazilian Version of the P-CPQ. Braz Dent J 20:169-174.

12. Jokovic a., Locker D, Guyatt G (2004) How well do parents know their children? implications for proxy reporting of child health-related quality of life. Qual Life Res 13:1297-1307.

13. Jokovic A, Locker D, Stephens M, Guyatt G (2003) Agreement between mothers and children aged 11-14 years in rating child oral health-related quality of life. Community Dent Oral Epidemiol 31:335-343.

14. Jokovic A, Locker D, Stephens M, Kenny D, Tompson B, Guyatt G (2003) Measuring Parental Perceptions of Child Oral Health-related Quality of Life. J Public Health Dent 63:67-72.

15. Kumar S, Kroon J, Lalloo R, Johnson NW (2016) Validity and reliability of short forms of parental-caregiver perception and family impact scale in a Telugu speaking population of India. Health Qual Life Outcomes 14:34

16. Malden PE, Thomson WM, Jokovic A, Locker D (2008) Changes in parentassessed oral health-related quality of life among young children following dental treatment under general anaesthetic. Community Dent Oral Epidemiol 36:108-117.

17. Marshman Z, Rodd H, Stern M, Mitchell C, Robinson PG (2007) Evaluation of the Parental Perceptions Questionnaire, a component of the COHQoL, for use in the UK . Community Dent Health 24:198-204.

18. McGrant C, Pang HN, Lo ECM, King NM, Hägg U, Samman N (2008) Translation and evaluation of a Chinese version of the child oral health-related quality of life measure. Int J Paediatr Dent 18:267-274.

19. Tellez M, Martignon S, Zuluaga J, Barreiro L, Builes L, Córdoba D, Gomez J (2010) Correlación de un Instrumento de Calidad de Vida relacionado con Salud Oral entre niños de 8 a 10 años y sus acudientes en Bogotá. Rev CES Odontol 23:9_ 15.

20. Thomson WM, Foster Page L a, Gaynor WN, Malden PE (2013) Short-form versions of the Parental-Caregivers Perceptions Questionnaire and the Family Impact Scale. Community Dent Oral Epidemiol 41:441-50.

21. Thomson WM, Foster Page L a, Malden PE, Gaynor WN, Nordin N (2014) Comparison of the ECOHIS and short-form P-CPQ and FIS scales. Health Qual Life Outcomes 12:36.

22. Zhang M, McGrath C, Hägg U (2007) Who knows more about the impact of malocclusion on children's quality of life, mothers or fathers? Eur J Orthod 29:180185.

\section{Pediatric Quality of Life Inventory ${ }^{\mathrm{TM}}$ Oral Health Scale ${ }^{\mathrm{TM}}$ (PedsQL-OH)}

1. Bendo CB, Paiva SM, Viegas CM, Vale MP, Varni JW (2012) The PedsQLTM Oral Health Scale: feasibility, reliability and validity of the Brazilian Portuguese version. Health Qual Life Outcomes 10:42-53.

2. Lin C-Y, Kumar S, Pakpour AH (2016) Rasch analysis of the Persian version of PedsQL(TM) Oral Health Scale: further psychometric evaluation on item validity including differential item functioning. Heal Promot Perspect 6:145-151. 
3. Pakpour AH, Yekaninejad MS, Zarei F, Hashemi F, Steele MM, Varni JW (2011) The PedsQLTM Oral Health Scale in Iranian children: Reliability and validity. Int J. Paediatr Dent 21:342-352.

4. Steele MM, Steele RG, Varni JW (2009) Reliability and Validity of the PedsQLTM Oral Health Scale: Measuring the Relationship Between Child Oral Health and Health-Related Quality of Life. Child Health Care 38:228-244.

\section{Pediatric Oral Health-Related Quality of Life (POQL)}

1. Braun PA, Lind KE, Henderson WG, Brega AG, Quissell DO, Albino J (2015) Validation of a pediatric oral health-related quality of life scale in Navajo children. Qual Life Res 24:231-239.

2. Huntington NL, Spetter D, Jones JA, Rich SE, Garcia RI, Spiro A (2011) Development and validation of a measure of pediatric oral health-related quality of life: The POQL. J Public Health Dent. 71:185-193.

3. Yazicioglu I, Jones JA, Cortés D, Rich S, Garcia R (2013) Hispanic parents' reading language preference and pediatric oral health-related quality of life. J Public Health Dent 73:329-338. 
Supplement 3: Rating of each EMPRO items and attribute for OHRQoL

Preschoolers (Age 0-5)

\begin{tabular}{|c|c|c|c|c|c|c|}
\hline & ATTRIBUTES & ECOHIS & SOHO & OH-ECQOL & DDQ & Michigan-OH \\
\hline & $\begin{array}{l}\text { CONCEPT AND MEASUREMENT } \\
\text { MODEL }\end{array}$ & 100.0 & 52.4 & 76.2 & 76.2 & 38.1 \\
\hline 1 & concept of measurement stated & ++++ & ++++ & ++++ & ++++ & +++ \\
\hline 2 & $\begin{array}{l}\text { obtaining and combining items } \\
\text { described }\end{array}$ & ++++ & +++ & ++++ & +++ & ++ \\
\hline 3 & $\begin{array}{l}\text { rationality for dimensionality and } \\
\text { scales }\end{array}$ & ++++ & ++ & - & ++ & ++ \\
\hline 4 & involvement of target population & ++++ & ++++ & ++++ & ++++ & ++ \\
\hline 5 & $\begin{array}{l}\text { scale variability described and } \\
\text { adequate }\end{array}$ & ++++ & + & +++ & ++ & + \\
\hline 6 & level of measurement described & ++++ & ++ & ++++ & ++++ & +++ \\
\hline \multirow[t]{3}{*}{7} & procedures for deriving scores & ++++ & ++ & +++ & ++++ & ++ \\
\hline & RELIABILITY - total score & 66.7 & 33.3 & 41.7 & 41.7 & 25.0 \\
\hline & Reliability: internal consistency & 66.7 & 33.3 & 41.7 & 41.7 & 25.0 \\
\hline 8 & data collection methods described & +++ & ++ & +++ & +++ & +++ \\
\hline 9 & Cronbach's alpha adequate & ++++ & +++ & ++ & +++ & ++ \\
\hline 10 & IRT estimates provided & - & - & - & - & - \\
\hline \multirow[t]{2}{*}{11} & testing in different populations & ++++ & n.a. & +++ & ++ & - \\
\hline & Reliability: reproducibility & 58.3 & 16.7 & 41.7 & & 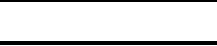 \\
\hline 12 & data collection methods described & +++ & ++ & ++ & - & - \\
\hline 13 & test-retest and time interval adequate & ++++ & ++ & ++ & - & - \\
\hline 14 & reproducibility coefficients adequate & +++ & - & ++++ & - & - \\
\hline \multirow[t]{2}{*}{15} & IRT estimates provided & - & - & - & - & - \\
\hline & VALIDITY & 100.0 & 46.7 & 93.3 & 55.6 & 55.6 \\
\hline 16 & content validity adequate & ++++ & +++ & ++++ & - & ++ \\
\hline 17 & construct/criterion validity adequate & ++++ & +++ & +++ & - & ++ \\
\hline 18 & sample composition described & ++++ & ++ & ++++ & +++ & +++ \\
\hline 19 & prior hypothesis stated & ++++ & +++ & ++++ & ++++ & +++ \\
\hline 20 & rational for criterion validity & n.a. & n.a. & n.a. & ++++ & ++++ \\
\hline \multirow[t]{2}{*}{21} & tested in different populations & ++++ & - & ++++ & +++ & ++ \\
\hline & RESPONSIVENESS & 77.8 & 100.0 & 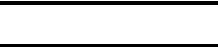 & & \\
\hline 22 & Adequacy of methods & ++++ & ++++ & - & - & - \\
\hline 23 & $\begin{array}{l}\text { description of estimated magnitude of } \\
\text { change }\end{array}$ & +++ & ++++ & - & - & - \\
\hline \multirow[t]{2}{*}{24} & $\begin{array}{l}\text { comparison of stable and unstable } \\
\text { groups }\end{array}$ & +++ & ++++ & - & - & - \\
\hline & INTERPRETABILITY & 66.7 & 33.3 & 0.0 & 11.1 & 33.3 \\
\hline 25 & rational of external criteria & +++ & ++ & + & ++ & ++ \\
\hline 26 & description of interpretation strategies & +++ & +++ & - & + & ++ \\
\hline \multirow[t]{4}{*}{27} & how data should be reported stated & +++ & + & + & - & ++ \\
\hline & OVERALL SCORE & 82.2 & 53.1 & 42.2 & 36.9 & 30.4 \\
\hline & BURDEN & & & & & \\
\hline & Burden: respondent & 44.4 & 44.4 & 0.0 & 33.3 & 44.4 \\
\hline 28 & skills and time needed & - & +++ & - & - & ++ \\
\hline 29 & impact on respondents & +++ & +++ & + & ++ & ++ \\
\hline \multirow[t]{2}{*}{30} & not suitable circumstances & +++ & + & + & +++ & +++ \\
\hline & Burden: administrative & 100.0 & 50.0 & 16.7 & 100.0 & 33.3 \\
\hline 31 & resources required & ++++ & ++ & - & ++++ & - \\
\hline 32 & time required & n.a. & n.a. & n.a. & n.a. & n.a. \\
\hline 33 & training and expertise needed & n.a. & n.a. & n.a. & n.a. & n.a. \\
\hline 34 & burden of score calculation & ++++ & +++ & ++ & ++++ & +++ \\
\hline
\end{tabular}




\section{Schoolchildren and Adolescents (Age 6-18)}

\begin{tabular}{|c|c|c|c|c|c|c|c|c|c|c|}
\hline & ATTRIBUTES & $\begin{array}{c}\text { CPQ } \\
11-14\end{array}$ & $\begin{array}{l}\text { Child- } \\
\text { OIDP }\end{array}$ & $\begin{array}{l}\text { Child- } \\
\text { OHIP }\end{array}$ & $\begin{array}{l}\text { CPQ } \\
8-10\end{array}$ & MIQ & $\begin{array}{c}\text { OHRQOL } \\
\text { Hypodontia }\end{array}$ & $\begin{array}{c}\text { Child- } \\
\text { DPQ }\end{array}$ & IFAQ & DFTO \\
\hline & $\begin{array}{l}\text { CONCEPT AND MEASUREMENT } \\
\text { MODEL }\end{array}$ & 90.5 & 85.7 & 85.7 & 71.4 & 85.7 & 47.6 & 76.2 & 47.6 & 38.1 \\
\hline 1 & concept of measurement stated & ++++ & ++++ & ++++ & ++++ & ++++ & +++ & ++++ & +++ & ++++ \\
\hline 2 & $\begin{array}{l}\text { obtaining and combining items } \\
\text { described }\end{array}$ & ++++ & +++ & ++++ & +++ & ++++ & +++ & ++ & +++ & - \\
\hline 3 & $\begin{array}{l}\text { rationality for dimensionality and } \\
\text { scales }\end{array}$ & +++ & +++ & ++++ & +++ & ++++ & ++++ & ++++ & +++ & +++ \\
\hline 4 & involvement of target population & ++++ & ++++ & ++++ & ++++ & +++ & ++++ & +++ & ++++ & - \\
\hline 5 & $\begin{array}{l}\text { scale variability described and } \\
\text { adequate }\end{array}$ & ++++ & +++ & ++++ & +++ & +++ & + & ++ & + & ++ \\
\hline 6 & level of measurement described & +++ & ++++ & - & +++ & ++++ & + & ++++ & ++ & - \\
\hline \multirow[t]{3}{*}{7} & procedures for deriving scores & ++++ & ++++ & ++++ & ++ & +++ & + & ++++ & + & +++ \\
\hline & RELIABILITY - total score & 66.7 & 66.7 & 50.0 & 44.4 & 66.7 & 66.7 & 44.4 & 33.3 & 16.7 \\
\hline & Reliability: internal consistency & 58.3 & 16.7 & 50.0 & 44.4 & 66.7 & 41.7 & 44.4 & 33.3 & \\
\hline 8 & data collection methods described & +++ & ++ & ++++ & +++ & ++++ & ++ & ++ & ++ & - \\
\hline 9 & Cronbach's alpha adequate & +++ & ++ & ++ & +++ & ++++ & +++ & ++++ & +++ & - \\
\hline 10 & IRT estimates provided & - & - & - & - & +++ & - & - & - & - \\
\hline \multirow[t]{2}{*}{11} & testing in different populations & ++++ & - & +++ & - & - & +++ & n.a. & n.a. & - \\
\hline & Reliability: reproducibility & 66.7 & 66.7 & 50.0 & 41.7 & 58.3 & 66.7 & 25.0 & 8.3 & 16.7 \\
\hline 12 & data collection methods described & +++ & +++ & +++ & +++ & +++ & +++ & ++ & + & ++ \\
\hline 13 & test-retest and time interval adequate & ++++ & ++++ & ++++ & +++ & ++++ & +++ & +++ & ++ & ++ \\
\hline 14 & reproducibility coefficients adequate & ++++ & ++++ & ++ & ++ & +++ & +++ & n.a. & - & + \\
\hline \multirow[t]{2}{*}{15} & IRT estimates provided & - & - & - & - & - & +++ & - & - & - \\
\hline & VALIDITY & 86.7 & 66.7 & 72.2 & 60.0 & 53.3 & 61.1 & 22.2 & & \\
\hline 16 & content validity adequate & ++++ & +++ & +++ & +++ & ++++ & +++ & + & ++ & - \\
\hline 17 & construct/criterion validity adequate & +++ & +++ & +++ & +++ & ++++ & +++ & ++ & - & - \\
\hline 18 & sample composition described & ++++ & +++ & ++++ & ++ & ++ & +++ & ++ & - & - \\
\hline 19 & prior hypothesis stated & +++ & +++ & +++ & +++ & ++ & +++ & + & - & - \\
\hline 20 & rational for criterion validity & n.a. & n.a. & +++ & n.a. & n.a. & +++ & + & n.a. & - \\
\hline \multirow[t]{2}{*}{21} & tested in different populations & ++++ & +++ & +++ & +++ & - & ++ & +++ & - & - \\
\hline & RESPONSIVENESS & 77,8 & 88,9 & 77,8 & 100 & & & & & \\
\hline 22 & Adequacy of methods & +++ & ++++ & +++ & ++++ & - & - & - & - & - \\
\hline 23 & $\begin{array}{l}\text { description of estimated magnitude of } \\
\text { change }\end{array}$ & ++++ & +++ & ++++ & ++++ & - & - & - & - & - \\
\hline \multirow[t]{2}{*}{24} & $\begin{array}{l}\text { comparison of stable and unstable } \\
\text { groups }\end{array}$ & +++ & ++++ & +++ & ++++ & - & - & - & - & - \\
\hline & INTERPRETABILITY & 88.9 & 33.3 & 22.2 & & 33.3 & 33.3 & 22.2 & & \\
\hline 25 & rational of external criteria & ++++ & +++ & ++ & - & ++ & ++ & ++ & - & - \\
\hline 26 & description of interpretation strategies & +++ & - & ++ & - & - & ++ & + & - & - \\
\hline \multirow[t]{4}{*}{27} & how data should be reported stated & ++++ & ++ & + & - & +++ & ++ & ++ & - & ++ \\
\hline & OVERALL SCORE & 82.1 & 68.3 & 61.6 & 55.2 & 47.8 & 41.8 & 33.0 & & \\
\hline & BURDEN & & & & & & & & & \\
\hline & Burden: respondent & 66.7 & 77.8 & 22.2 & 22.2 & 77.8 & 33.3 & 55.6 & 11.1 & 33.3 \\
\hline 28 & skills and time needed & ++ & +++ & + & + & ++++ & - & +++ & ++ & ++ \\
\hline 29 & impact on respondents & ++++ & +++ & + & + & +++ & +++ & +++ & + & +++ \\
\hline \multirow[t]{2}{*}{30} & not suitable circumstances & +++ & ++++ & +++ & +++ & +++ & ++ & ++ & + & + \\
\hline & Burden: administrative & 50.0 & 91,7 & 33.3 & 50.0 & 83.3 & & 100.0 & 0.0 & \\
\hline 31 & resources required & - & ++++ & - & +++ & ++++ & - & ++++ & - & - \\
\hline 32 & time required & n.a. & ++++ & n.a. & n.a. & n.a. & n.a. & n.a. & n.a. & n.a. \\
\hline 33 & training and expertise needed & n.a. & +++ & n.a. & n.a. & n.a. & n.a. & n.a. & n.a. & n.a. \\
\hline 34 & burden of score calculation & ++++ & ++++ & +++ & ++ & +++ & - & ++++ & + & - \\
\hline
\end{tabular}

Explanation: ++++ 4 (strongly agree); +++ 3; ++ 2; + 1 (strongly disagree); - no information; n.a. not applicable. The higher the agreement the better the rating. 
Children and Adolescents (Age 0-18)

\begin{tabular}{|c|c|c|c|c|c|}
\hline & ATTRIBUTES & FIS & POQL & P-CPQ & PedsQI-OH \\
\hline & $\begin{array}{l}\text { CONCEPT AND MEASUREMENT } \\
\text { MODEL }\end{array}$ & 85.7 & 95.2 & 66.7 & 90.5 \\
\hline 1 & concept of measurement stated & +++ & +++++ & ++++ & ++++ \\
\hline 2 & $\begin{array}{l}\text { obtaining and combining items } \\
\text { described }\end{array}$ & ++++ & ++++ & +++ & ++++ \\
\hline 3 & $\begin{array}{l}\text { rationality for dimensionality and } \\
\text { scales }\end{array}$ & ++++ & ++++ & + & ++++ \\
\hline 4 & involvement of target population & ++++ & ++++ & ++++ & $\overline{++++}$ \\
\hline 5 & $\begin{array}{l}\text { scale variability described and } \\
\text { adequate }\end{array}$ & ++++ & +++ & ++++ & ++++ \\
\hline 6 & level of measurement described & +++ & ++++ & +++ & +++ \\
\hline \multirow[t]{3}{*}{7} & procedures for deriving scores & $\overline{+++}$ & ++++ & $\overline{+++}$ & $\overline{++++}$ \\
\hline & RELIABILITY - total score & 55.6 & 50.0 & 66.7 & 58.3 \\
\hline & Reliability: internal consistency & 55.6 & 50.0 & 58.3 & 41.7 \\
\hline 8 & data collection methods described & ++++ & +++ & +++ & ++++ \\
\hline 9 & Cronbach's alpha adequate & +++ & +++ & ++++ & +++ \\
\hline 10 & IRT estimates provided & - & - & - & - \\
\hline \multirow[t]{2}{*}{11} & testing in different populations & n.a. & +++ & +++ & - \\
\hline & Reliability: reproducibility & 50.0 & 41.7 & 66.7 & 58.3 \\
\hline 12 & data collection methods described & ++++ & ++++ & ++++ & ++++ \\
\hline 13 & test-retest and time interval adequate & +++++ & +++ & ++++ & +++ \\
\hline 14 & reproducibility coefficients adequate & - & ++ & ++++ & +++ \\
\hline \multirow[t]{2}{*}{15} & IRT estimates provided & - & - & - & - \\
\hline & VALIDITY & 93.3 & 66.7 & 86.7 & 80.0 \\
\hline 16 & content validity adequate & ++++ & +++ & ++++ & ++++ \\
\hline 17 & construct/criterion validity adequate & ++++ & +++ & ++++ & ++++ \\
\hline 18 & sample composition described & ++++ & $\overline{+++}$ & $\overline{++++}$ & ++++ \\
\hline 19 & prior hypothesis stated & +++++ & +++ & ++++ & ++++ \\
\hline 20 & rational for criterion validity & n.a. & n.a. & n.a. & n.a. \\
\hline \multirow[t]{2}{*}{21} & tested in different populations & +++ & +++ & ++ & - \\
\hline & RESPONSIVENESS & 88.9 & 66.7 & 77.8 & \\
\hline 22 & Adequacy of methods & ++++ & +++ & ++++ & - \\
\hline 23 & $\begin{array}{l}\text { description of estimated magnitude of } \\
\text { change }\end{array}$ & ++++ & +++ & ++++ & - \\
\hline \multirow[t]{2}{*}{24} & $\begin{array}{l}\text { comparison of stable and unstable } \\
\text { groups }\end{array}$ & ++++ & +++ & +++ & - \\
\hline & INTERPRETABILITY & 77.8 & 66.7 & & \\
\hline 25 & rational of external criteria & +++ & ++++ & ++ & - \\
\hline 26 & description of interpretation strategies & +++ & - & - & - \\
\hline \multirow[t]{4}{*}{27} & how data should be reported stated & ++++ & ++++ & - & - \\
\hline & OVERALL SCORE & 80.3 & 69.0 & 59.6 & 45.8 \\
\hline & BURDEN & & & & \\
\hline & Burden: respondent & & 44.4 & 22.2 & 55.6 \\
\hline 28 & skills and time needed & - & ++ & - & +++ \\
\hline 29 & impact on respondents & $\overline{+++}$ & ++ & ++ & $\overline{+++}$ \\
\hline \multirow[t]{2}{*}{30} & not suitable circumstances & - & +++ & ++ & ++ \\
\hline & Burden: administrative & 100.0 & 100.0 & & 100.0 \\
\hline 31 & resources required & ++++ & ++++ & - & ++++ \\
\hline 32 & time required & n.a. & n.a. & n.a. & n.a. \\
\hline 33 & training and expertise needed & n.a. & n.a. & n.a. & n.a. \\
\hline 34 & burden of score calculation & ++++ & ++++ & - & ++++ \\
\hline
\end{tabular}


Supplement 4: EMPRO rating* and score of 'Alternative forms of administration' Attribute.

\begin{tabular}{|c|c|c|c|c|c|c|c|c|c|}
\hline & \multicolumn{4}{|c|}{ Administration Forms } & \multicolumn{5}{|c|}{ Short Forms } \\
\hline & $\begin{array}{l}\text { Child-OIDP } \\
\text { Self- } \\
\text { administered }\end{array}$ & $\begin{array}{l}\text { CPQ8-10 } \\
\text { Interview }\end{array}$ & $\begin{array}{l}\text { CPQ11-14 } \\
\text { Interview }\end{array}$ & $\begin{array}{l}\text { CPQ11-14 } \\
\text { Telephone }\end{array}$ & DDQ-8 & $\begin{array}{l}\text { Child- } \\
\text { OHIP } \\
19 \text { items }\end{array}$ & $\begin{array}{l}\text { CPQ11-14 } \\
8 \text { items } \\
\text { CPQ11-14 } \\
16 \text { item }\end{array}$ & $\begin{array}{l}\text { FIS } \\
8 \text { items }\end{array}$ & $\begin{array}{l}\text { P-CPQ } \\
16 \text { items }\end{array}$ \\
\hline $\begin{array}{l}\text { Metrics } \\
\text { characteristics } \\
\text { of alternative } \\
\text { forms }\end{array}$ & +++ & +++ & +++ & +++ & ++ & +++ & +++ & ++++ & ++++ \\
\hline $\begin{array}{l}\text { Comparability } \\
\text { of alternative } \\
\text { forms }\end{array}$ & ++++ & ++++ & ++++ & ++++ & ++ & ++++ & ++++ & ++++ & ++++ \\
\hline SCORE & 83.3 & 83.3 & 83.3 & 83.3 & 33.3 & 83.3 & 83.3 & 100 & 100 \\
\hline
\end{tabular}

